\author{
RESEARCH ARTICLE \\ 10.1029/2019JC015221 \\ Key Points: \\ - Primary production in East \\ Antarctic fast ice is not Fe-limited \\ during late spring/early summer \\ - Iron in suspended sediment \\ entrapped during ice formation \\ supports primary production in the \\ ice \\ - Windblown dust from ice-free \\ coastal landmasses in the Vestfold \\ Hills contributes significantly to the \\ total iron pool in Davis fast ice
}

Supporting Information:

- Supporting Information S1

- Figure S1

Correspondence to:

L. Duprat,

luis.duprat@utas.edu.au

Citation:

Duprat, L., Kanna, N., Janssens, J., Roukaerts, A., Deman, F., Townsend, A. T., et al. (2019). Enhanced Iron Flux to Antarctic Sea Ice via Dust Deposition From Ice-Free Coastal Areas. Journal of Geophysical Research: Oceans, 124, 8538-8557. https://doi.org/10.1029/ 2019JC015221

Received 15 APR 2019 Accepted 20 SEP 2019 Accepted article online 25 OCT 2019 Published online 4 DEC 2019

\section{Enhanced Iron Flux to Antarctic Sea Ice via Dust Deposition From Ice-Free Coastal Areas}

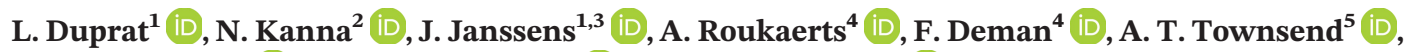 \\ K. M. Meiners ${ }^{6,7}$ iD, P. van der Merwe ${ }^{7}$ iD, and D. Lannuzel ${ }^{1,6}$ iD \\ ${ }^{1}$ Institute for Marine and Antarctic Studies, University of Tasmania, Hobart, Tasmania, Australia, ${ }^{2}$ Arctic Research \\ Center, Hokkaido University, Sapporo, Japan, ${ }^{3}$ Now at Commonwealth Scientific and Industrial Research Organisation \\ (CSIRO), Hobart, Tasmania, Australia, ${ }^{4} \mathrm{AMGC}$ Department, Vrije Universiteit Brussel, Brussels, Belgium, ${ }^{5}$ Central \\ Science Laboratory, University of Tasmania, Hobart, Tasmania, Australia, ${ }^{6}$ Australian Antarctic Division, Kingston, \\ Tasmania, Australia, ${ }^{7}$ Antarctic Climate and Ecosystems Cooperative Research Centre, Hobart, Tasmania, Australia
}

(C)2019. American Geophysical Union. All Rights Reserved.

\begin{abstract}
Antarctic sea ice is an important temporal reservoir of iron which can boost primary production in the marginal ice zone during the seasonal melt. While studies have reported that Antarctic fast ice bears high concentrations of iron due to the proximity to coastal sources, less clear are the biogeochemical changes this iron pool undergoes during late spring. Here we describe a 3-week time series of physical and biogeochemical data, including iron, from first-year coastal fast ice sampled near Davis Station (Prydz Bay, East Antarctica) during late austral spring 2015. Our study shows that dissolved and particulate iron concentrations in sea ice were up to two orders of magnitude higher than in under-ice seawater. Furthermore, our results indicate a significant contribution of lithogenic iron from the Vestfold Hills (as deduced from the comparison with crustal element ratios) to the particulate iron pool in fast ice after a blizzard event halfway through the time series. Windblown dust represented approximately $75 \%$ of the particulate iron found in the ice and is a potential candidate for keeping concentrations of soluble iron stable during our observations. These results suggest that iron entrapped during ice formation, likely from sediments, as well as local input of coastal dust, supports primary productivity in Davis fast ice. As ice-free land areas are likely to expand over the course of the century, this work highlights the need to quantify iron inputs from continental Antarctic dust and its bioavailability for ice algae and phytoplankton.

Plain Language Summary Oceanic single-celled algae are the base of the ocean food web and play an important role in the Earth climate. In the Southern Ocean, the growth of these microorganisms is limited by the naturally low concentration of iron in the seawater. Microalgae benefit from the presence of the Antarctic sea ice since iron is highly concentrated in sea ice relative to the seawater. Less clear though is the contribution of the potential sources of iron to the sea ice. We collected and analyzed sea ice cores for a series of parameters, including iron, from first-year coastal sea ice sampled near Davis Station (Prydz Bay, East Antarctica) during late austral spring 2015. Our results suggest that iron entrapped during ice formation, likely from seafloor sediments, as well as dust blown by winds from the neighboring Vestfold Hills, are the main sources of iron to Davis coastal sea ice. Since we can expect the expansion of ice-free areas and exposed grounds over the course of this century, our results highlight the need to quantify the amount of iron coming from continental Antarctic dust and to access if microalgae can use this form of iron for their basic physiological needs.
\end{abstract}

\section{Introduction}

The ubiquitous scarcity of the key micronutrient iron (Fe) makes the Southern Ocean the largest highnutrient, low-chlorophyll area on Earth (Martin, 1990; Martin et al., 1991). Photosynthetic microalgae require Fe to fix carbon dioxide and, ultimately, fuel ocean food webs (Benner, 2011). While the importance of Fe for marine primary production and carbon sequestration is well recognized (Blain et al., 2007; Boyd et al., 2007; Martin \& Fitzwater, 1988; Moore et al., 2001), less is known about the bioavailability of the different sources of Fe to phytoplankton. Iron can coexist in a range of different sizes, forms, and complexation states in the ocean. Direct uptake studies (Hudson \& Morel, 1993; Morel et al., 2008) and general kinetic 


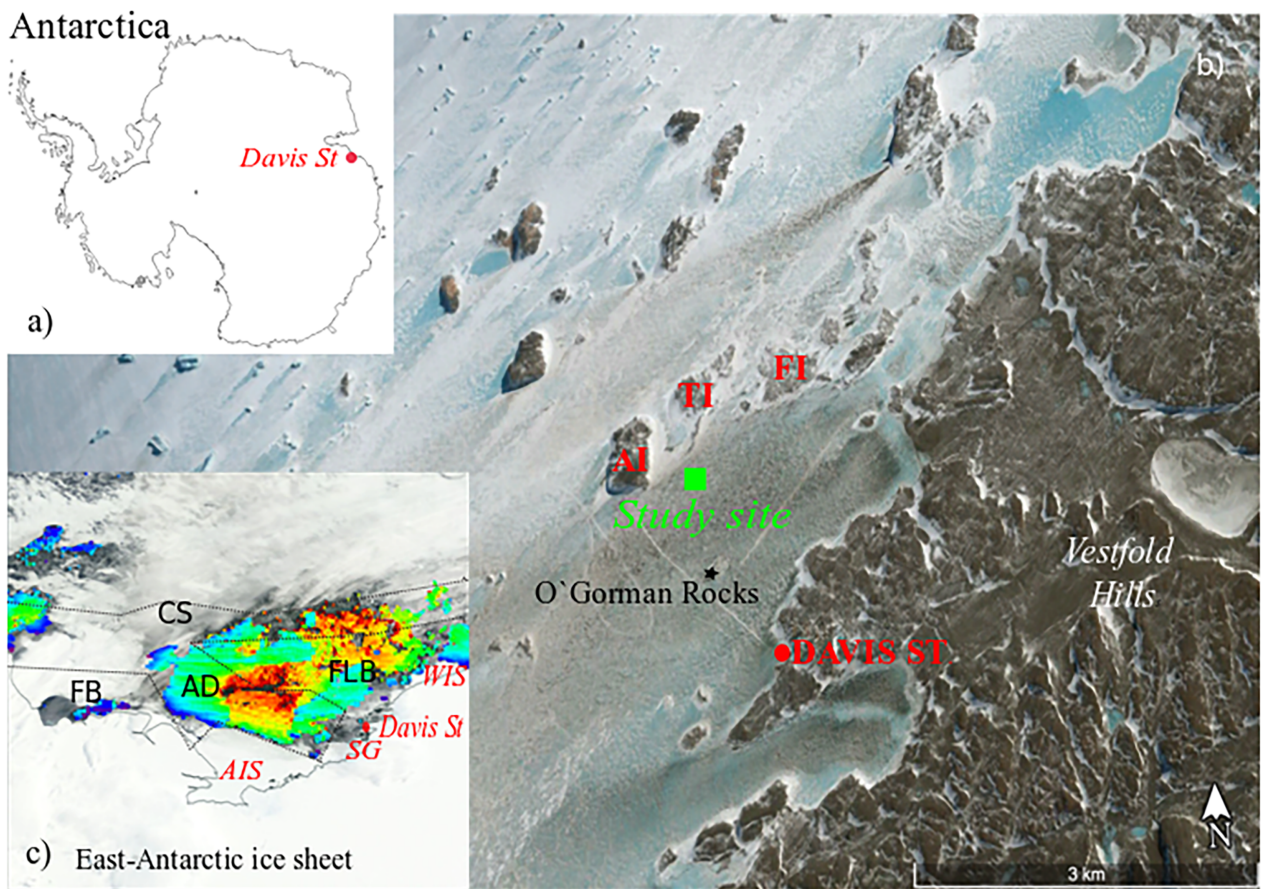

Figure 1. (a) Map of Davis Station location ( $68^{\circ} 34^{\prime} 36^{\prime \prime} \mathrm{S}, 77^{\circ}$ 58 $03^{\prime \prime}$ E), East Antarctica. Image is courtesy of Google Earth (Google Earth Pro 7 V.3.2.5776, 2015). (b) Satellite image of Abatus Bay (Davis sea ice) obtained on the 10/13/2015 with geographic abbreviations: AI (Anchorage Island), TI (Trigwell Island) and FI (Flutter Island). (c) Chlorophyll color image of Prydz Bay, late spring 2015 (NASA Earth Observing System Data and Information System, 2018). Dotted lines indicate the general geomorphology of the bay: AD (Amery depression), FB (Fram Bank), FLB (Four Ladies Bank) and CS (Continental slope). In red, the main glacial features of the area: AIS (Amery Ice Shelf), SG (Sørsdal Glacier), and WIS (West Ice Shelf).

models (Hudson \& Morel, 1990) have demonstrated that unchelated inorganic Fe is the most readily bioavailable form to microalgae. However, at ocean $\mathrm{pH}$ and oxic conditions, this unchelated form is hardly soluble and precipitates as ferric oxyhydroxide solid complexes $\left(\mathrm{Fe}(\mathrm{OH})_{\mathrm{x}}\right)$, leading to extremely low concentrations of this Fe specie in seawater (Lis et al., 2015; Millero, 1998). Filtrations and analyses enable the categorization of Fe into particulate $(>0.2 \mu \mathrm{m})$ and "dissolved" $(<0.2 \mu \mathrm{m})$ fractions. Still, the chemical forms of Fe within these fractions remain largely speculative (Wells et al., 1995). Today there is evidence that Fe is present in seawater mostly in the small colloidal phase, which is included in the operationally defined "dissolved" fraction and almost entirely complexed by organic ligands (Gledhill \& Buck, 2012; Wu et al., 2001; Wu \& Luther, 1994). The bioavailability of dissolved Fe (DFe) depends in part on its chemical nature (Lis et al., 2015; Wells \& Goldberg, 1991). On the other hand, the bioavailability of the particulate $\mathrm{Fe}(\mathrm{PFe})$ fraction is a function of the thermodynamic stability and kinetic lability of this phase (Chen et al., 2003; Kuma \& Matsunaga, 1995). Although relatively low as a percentage, when abundant, PFe can become a significant source for phytoplankton. Many studies have now pointed toward the importance of the particulate fraction in replenishing the DFe pool via thermal, photochemical, and ligand-mediated dissolution (Borer et al., 2005; Kraemer, 2004; Sulzberger et al., 1989).

Despite widespread Fe limitation, intense and regularly occurring springtime algal blooms are observed in the Southern Ocean marginal ice zones (Sullivan et al., 1993). This phenomenon has been linked to the melting of the seasonal sea ice, which promotes the release of Fe to the seawater and surface water stratification (Grotti et al., 2005; Lannuzel et al., 2007, 2008, 2010; van der Merwe et al., 2009). In contrast to pack ice, which relies on biological activity to actively concentrate Fe (Lannuzel et al., 2014), fast ice (i.e., sea ice fastened to the shore) can incorporate high concentrations of Fe simply due to its proximity to lithogenic sources such as eroded continental rocks, sediments, and dust (Lannuzel et al., 2016). Melting fast ice, therefore, has the potential to trigger local phytoplankton blooms, as previously observed near Casey and McMurdo Stations in Antarctica (de Jong et al., 2013; Lannuzel et al., 2014; van der Merwe, Lannuzel, Bowie, \& Meiners, 2011). The geographic location of growing fast ice can also greatly influence the amount of Fe stored during the initial phase of sea-ice formation, partly dictating the magnitude and nature of the 
sea-ice Fe pool. Naturally Fe-fertilized biological hotspots other than sea ice include areas near melting glaciers (Gerringa et al., 2012; Herraiz-Borreguero et al., 2016; Raiswell et al., 2008), icebergs (Duprat et al., 2016), and areas affected by sediment resuspension as well as downstream of windblown dust (de Jong et al., 2013). Importantly, some coastal environments are prone to the fastest climatic changes, those which could cause an expansion of up to $25 \%$ of ice-free areas across the Antarctic landmass by the end of the century (Lee et al., 2017). Exposed dust and rocks may subsequently increase the fertilization of the Southern Ocean due to its impact on the Fe distribution in coastal sea ice and potentially further offshore (Lannuzel et al., 2016). Ice-free areas such as the McMurdo Dry Valleys in Antarctica have been identified as a source of Fe to the Ross Sea via airborne transport, potentially boosting local marine productivity (de Jong et al., 2013). Nevertheless, the magnitude and effectiveness of extended ice-free grounds on coastal fertilization and carbon sequestration carry large uncertainties given the predominant refractory nature of Fe content in the dust (Mahowald et al., 2009).

Here we present results from a time series undertaken at a coastal site in Prydz Bay to provide new insights into sea-ice Fe biogeochemistry during late spring to summer transition. The time series also encompasses a blizzard event halfway through our visit, allowing for a dichotomous comparison between these two periods. Our study site (Figure 1) is surrounded by important climate-sensitive features such as the Amery Ice Shelf (AIS) and nearby glaciers, year-round sea ice, and one of the largest ice-free zones on the East Antarctic coast (the Vestfold Hills). Our first hypothesis is that fast ice plays an important role by delivering potentially bioavailable Fe to the waters of Prydz Bay, the third most productive polynya area in Antarctica (Arrigo et al., 2015; Figure 1c). Our second hypothesis is that the Vestfold Hills represent a significant source of aeolian Fe dust to Prydz Bay. Findings from this study will help to assess the response of coastal Antarctic productivity to Antarctica's changing cryosphere.

\section{Materials and Methods}

\subsection{Study Site}

The study site was located in the Abatus Bay, approximately $2 \mathrm{~km}$ north of Davis Station ( $68^{\circ} 34^{\prime} 36^{\prime \prime} \mathrm{S}, 77^{\circ}$ $58^{\prime} 03^{\prime \prime}$ E), East Antarctica. The area is on the northeast side of the greater Prydz Bay area, bounded by the Breidnes Peninsula in the Vestfold Hills, O'Gorman Rocks, Anchorage Island, Trigwell Island, and Flutter Island (Figure 1b). The site was situated $600 \mathrm{~m}$ north of O'Gorman Rocks (a small rocky outcrop) and $200 \mathrm{~m}$ southeast of Anchorage Island in an area of undeformed sea ice and with a maximum water depth of $20 \mathrm{~m}$. The sampling area was located upwind from Davis Station (prevailing winds) and other operations in the vicinity of the station and off-limits to unauthorized personnel. No sign of foot or vehicle prints or other human activity was present at the location during the sampling period.

\subsection{Cleaning Procedures}

All plasticware including low-density polyethylene (LDPE) sampling bottles, polypropylene (PP) melting containers, and carboys, as well as all equipment used directly in contact with the samples, were cleaned as follows: LDPE bottles were immersed in $2 \%$ (v:v) Decon90 for one week and then rinsed three times with reverse osmosis water and three times with ultra-high purity water (UHP water, Barnstead) before being soaked in 50\% (v:v) $\mathrm{HCl}$ (analytical grade, Merck) for one month. After acid cleaning, bottles were rinsed five times with UHP water in a class-100 laminar flow hood. Bottles were then filled with 1\% (v:v) $\mathrm{HCl}$ (ultrapure, Seastar Baseline) and stored in triple ziplock bags until use. During sampling, bottles were rinsed three times with the sample material immediately before collection. Between sampling days, all plastic equipment (Teflon ${ }^{\circledR}$ filtration sets, plastic tubing, plastic scoops, and PP melting containers) were rinsed with UHP water and soaked in an acid bath (10-20\% (v:v) HCl, according to Nalgene ${ }^{\circledR}$ recommendations for each material) and then rinsed thoroughly before use. All glassware used for organic carbon and nitrogen filtrations were soaked in a $2 \%$ (v:v) $\mathrm{HCl}$ solution (analytical grade, Merck), rinsed with UHP water, wrapped in aluminum foil, and heated at $450^{\circ} \mathrm{C}$ for 4 hours.

\subsection{Sample Collection}

Snow, sea ice, "deep brine," and seawater were obtained on six different dates, converted to Julian days: 320 , 325, 327, 330, 333, and 336. All samples were collected and analyzed using trace metal clean protocols as described by Lannuzel et al. (2006) and van der Merwe et al. (2009). Samples were collected on consecutive 
dates upwind from each other to minimize cross-contamination, with an isolated zone allocated for the trace metal ice coring. Expeditioners wore clean room garments (Tyvek overall, overshoes, and polyethylene gloves) over their warm clothing. Timeseries cores were spaced apart from one another by approximately $0.4 \mathrm{~m}$, in a way to balance both the spatial heterogeneity and work disturbance effects. All items used for sample collection and storage were acid-cleaned and sealed in plastic bags.

On each sampling day, snow was collected from an area approximately $10 \mathrm{~m}$ away from the coring site using an acid-cleaned polyethylene hand shovel and stored in a 3.8-L widemouthed Nalgene ${ }^{\circledR}$ polyethylene bottle. The snow was left to melt at room temperature within the station laboratory where it was then processed for Fe and Chla measurements. Four sea-ice cores were collected from each site: The first core was dedicated to temperature and salinity measurements, the second and third for Chla and particulate organic matter (POC and PON) analyses, and the fourth core for trace metal analyses. Cores were sampled $0.1 \mathrm{~m}$ apart to minimize between-core spatial variability. They were drilled using an electric-powered, electro-polished stainless steel corer of 0.14-m internal diameter (Lichtert Industrie, Belgium), previously shown to be noncontaminating for trace metals (Lannuzel et al., 2006; van der Merwe et al., 2009). Ice cores were sectioned in the field starting from the top using a medical-grade bone saw (Richards Analytical). Samples for salinity, POC and PON, were cut every $0.1 \mathrm{~m}$ along the whole ice core. For Chla and Fe quantification, seven distinctive sections (here and after referred to S1-S7) were obtained by cutting two top sections of $0.2 \mathrm{~m}$ each (S1 and S2), two bottom sections of $0.05 \mathrm{~m}$ each (S6 and S7), and one middle section (S4) of $0.1 \mathrm{~m}$ starting $0.4 \mathrm{~m}$ away from the base of the ice. The remaining core length left between S2 and S4 and between S4 and S6 was designated S3 and S5, respectively. This provides a sequential top-bottom S1 to S7 core profile (Figure 2). Cores were kept in acid-cleaned plastic bags and stored frozen at $-20^{\circ} \mathrm{C}$ in the dark until further processing.

"Deep brine" was collected after determination of the depth of the sea-ice $-5^{\circ} \mathrm{C}$ isotherm. The core was drilled to the chosen depth and then removed, allowing the brine to drain and fill the (sack) hole. During this process, the holes were covered with plastic plugs to avoid airborne contamination. The brine was then collected from the hole using a peristaltic pump (E/S portable sampler, Masterflex) and acid-cleaned Masterflex $^{\circledR}$ tubing. Underlying seawater was collected at $\sim 0-, 3-$, and 10-m depths (hereafter referred to as SW0, SW3, and SW10) using a custom-made polycarbonate 7-L Helmond-Byrne (H-B) water sampler suspended from a Kevlar line and triggered using a Teflon ${ }^{\circledast}$ messenger (Sedwick et al., 1997). The sampler was deployed through three holes drilled side by side on the first sampling day. Seawater and brine samples were distributed into several acid-washed 1-L LDPE Nalgene ${ }^{\circledR}$ bottles avoiding light exposure as much as possible until further processing for the suite of parameters described in the section below.

In the Davis Station laboratories, sectioned cores were rinsed with UHP water, placed into individual acid-cleaned sealable PP buckets, and allowed to melt in the dark at room temperature. Melted samples were processed as soon as possible to avoid sample warming, limiting any further biological activity (Rintala et al., 2014). After each day, the saw, ice corer, and shovel were abundantly rinsed with UHP water, dried under a class-100 laminar flow hood and stored in triple plastic bags until next use.

\subsection{Sample Processing and Analytical Methods}

\subsubsection{Physical Variables}

Ice temperatures were measured using a testo temperature probe $\left( \pm 0.1^{\circ} \mathrm{C}\right.$ precision $)$ following insertion into 4-mm holes freshly drilled into the ice core every $0.05 \mathrm{~m}$. Bulk salinity of each $0.1-\mathrm{m}$ melted ice sections and brines was measured using a Thermo Scientific Orion (Model 125A Plus) conductivity meter $\left( \pm 0.1^{\circ} \mathrm{C}\right.$ precision). Brine volume fractions $\left(\mathrm{V}_{\mathrm{b}} / \mathrm{V}\right)$ were calculated according to Cox and Weeks (1988) using temperature and bulk salinity values. Where salinity and temperature profiles had different depth resolutions, the temperature was linearly interpolated to match the salinity. Since changes in the biogeochemical parameters can be explained by convective overturning, allowing nutrient supply from the seawater to the sea ice, the porous-medium mush-Rayleigh number $(\mathrm{Ra})$ was calculated. The original set of parameters proposed by Notz and Worster (2008) for the Ra formulation was used, following recommendations in Vancoppenolle et al. (2013).

2.4.2. Particulate Organic Carbon and Nitrogen

Snow, seawater, brines, and melted ice samples for POC and PON quantification were gently homogenized before filtration $(0.2-2.5 \mathrm{~L})$. Particulate material was collected by filtration on preheated $\left(450^{\circ} \mathrm{C}\right.$, for $\left.24 \mathrm{hr}\right)$ 


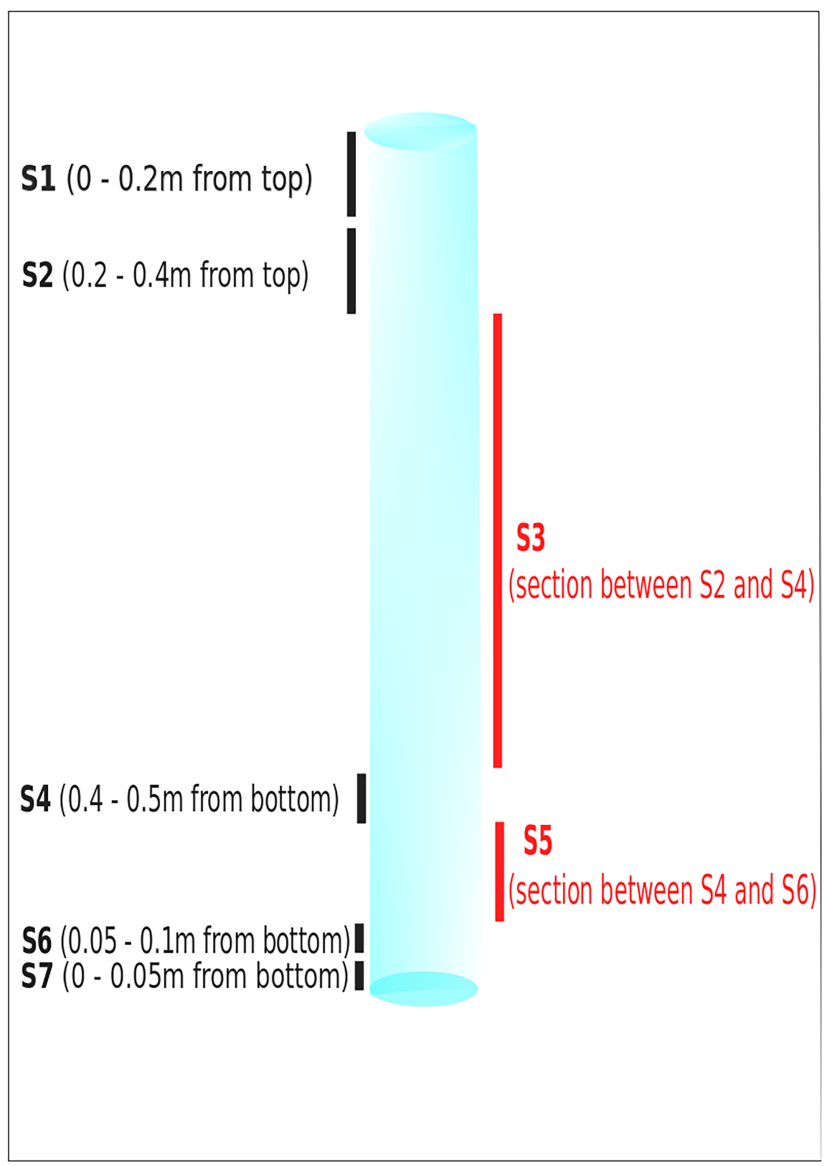

Figure 2. Schematic of the vertical sampling procedure for ice cores used for Fe and Chla profile determination.

quartz filters (0.7- $\mu \mathrm{m}$ nominal porosity, MGF Sartorius). Samples were dried overnight at $60^{\circ} \mathrm{C}$ and stored in the dark at room temperature $\left(20^{\circ} \mathrm{C}\right)$ in precombusted scintillation vials until further processing for isotopic composition at the Vrije Universiteit in Brussels, Belgium. Prior to analysis, inorganic carbon was removed from the filters by 24-hr exposure to concentrated $\mathrm{HCl}$ fumes inside a closed glass container. Filters were packed in silver cups and analyzed using an elemental analyzer (EuroEA3000, Eurovector) coupled online via a ConFlo III interface to a Thermo Delta V isotope ratio mass spectrometer. POC and PON detection limits were calculated as $3 \mathrm{x}$ the standard deviation of the procedure blanks, determined as 3.3 and $2.2 \mu \mathrm{M}$, respectively $(\mathrm{n}=4)$.

\subsubsection{Chlorophyll- $a$}

Ice cores for Chla analysis were melted at room temperature in the dark (Rintala et al., 2014). Immediately after melting, ice core sections as well as brine and seawater samples were then filtered under low vacuum $(<0.13$ bar) onto GF/F filters. The filtered volume $(0.1-1.5 \mathrm{~L})$ depended on the visible organic content and care was taken not to clog the filter. Filters were stored individually in plastic holders at $-80^{\circ} \mathrm{C}$ in the dark until analysis. Chla concentrations were determined fluorometrically with a Turner Designs 10AU fluorometer (in vitro detection limit $0.02 \mu \mathrm{g} / \mathrm{L}$ ) after extraction with $90 \%$ acetone for 12 hours. Fluorescence was measured at $750 \mathrm{~nm}$ for phaeopigment-corrected Chla determination after acidification with $0.1 \mathrm{~N} \mathrm{HCl}$ according to Arar and Collins (1997).

\subsubsection{Iron}

As soon as the snow and ice sections were melted, Fe size fractionation was obtained via filtration using a Teflon $^{\circledast}$ perfluoroalkoxy filtration apparatus (Savillex, USA) onto a $0.2-\mu \mathrm{m}$ pore size $47-\mathrm{mm}$ diameter polycarbonate membrane filter (Sterlitech) and under gentle vacuum $(<0.13$ bar) to avoid algal cell lysis. The process was repeated for the brine and seawater samples. In LDPE bottles for DFe analysis, $60 \mathrm{ml}$ of 
filtrate was collected. A second (sub) filtrate was collected to obtain the sFe using $0.02-\mu \mathrm{m}$ Whatman ${ }^{\circledR}$ Anotop $^{\circledast}$ syringe filters connected to Tygon ${ }^{\circledR}$ tubing mounted on a peristaltic pump set at $1 \mathrm{ml} / \mathrm{min}$. The membrane was successively rinsed with $10 \%$ v:v ultrapure $\mathrm{HCl}$ (Seastar Baseline, choice Analytical) and UHP water for a combined time of 1 hour before circulating the DFe fraction onto the $0.02-\mu \mathrm{m}$ membrane. The first $100 \mathrm{ml}$ were discarded before the final collection of the sFe fraction. Filter blanks were also prepared following the same procedure, minus the addition of samples. Dissolved and sFe samples were then acidified to $\mathrm{pH} \sim 1.8$ by adding $1 \%$ of $12-\mathrm{M}$ ultrapure $\mathrm{HCl}$ (Seastar Baseline, choice Analytical) to the samples. Bottles were triple bagged and stored at room temperature until analyses. Polycarbonate filters with the retained particulate fraction ( $\mathrm{PFe}>0.2 \mu \mathrm{m}$ ) were placed into acid clean polystyrene petri dishes, triple bagged, and stored at $-20^{\circ} \mathrm{C}$ in the dark until further processing and analyses in Australia.

2.4.4.1. Soluble and Dissolved Fe Analysis

An automated off-line sample system (seaFAST-pico ${ }^{\mathrm{TM}}$, Elemental Scientific; Nobias Chelate-PA1 resin) was used to preconcentrate trace metals and remove sea-ice and seawater filtrate matrices from our undiluted samples according to the method described by Wuttig et al. (2019). In-house testing proved the capability of the seaFAST system for accurate Fe determination over the large range of salinities encountered in this study. The method accuracy was evaluated through extensive analysis of a range of oceanographic standards where samples concentrations were found to agree with consensus values to within $\pm 6 \%$ and percentage recovery of $104 \pm 9(\mathrm{n}=33$; salinity range $0-60 \mathrm{~g} / \mathrm{kg})$ for Fe (Wuttig et al., 2019). Preconcentration factors ranging from 10x (snow, bottom sea ice, and brines) to 40x (sea ice and seawater) were chosen to provide resultant analyte values. Concentrations of $\mathrm{sFe}$ and $\mathrm{DFe}$ were then determined at the Central Science Laboratory (Hobart, Australia) using a sector field inductively coupled plasma mass spectrometer (SF-ICP-MS, Element 2) according to the methodology described by Wuttig et al. (2019).

The SF-ICP-MS was prepared for trace metal analysis with a clean sample introduction front end including sampler cones, torch, spray chamber, pump tubing, and nebulizer, with lengthy acid purging. During the period of analysis, the instrument was used exclusively for low-Fe level work. Before sample analysis, the instrument was purged with alternate $5 \%(\mathrm{v}: \mathrm{v}) \mathrm{HCl}$ and $5 \%(\mathrm{v}: \mathrm{v}) \mathrm{HNO}_{3}$ solutions for 1 hour to ensure residual traces from previous analysis were not present. Then, the instrument was conditioned to match our sample matrix using a $10 \%$ (v:v) $\mathrm{HNO}_{3}$ ultrapure solution. A linear calibration curve was obtained each day using four standards of Fe: $0 \mathrm{ppb}(0 \mathrm{nM}), 1 \mathrm{ppb}(17.9 \mathrm{nM}), 5 \mathrm{ppb}(89.5 \mathrm{nM})$, and $10 \mathrm{pbb}(179 \mathrm{nM})$ prepared from mixed element solutions (QCD Analysts, MISA suite of solutions, VHG Labs, LGC Standards, Manchester, $\mathrm{NH}, \mathrm{USA}$ ), all in $10 \%$ (v:v) $\mathrm{HNO}_{3}$. Indium (In) as an internal standard was added to all blanks, standards, and samples at a concentration of $10 \mathrm{ppb}(87.1 \mathrm{nM})$. After calibration and rinsing, the calibration blank was analyzed in triplicate to ensure a low instrument baseline prior to sample analysis. A 2.5-min rinse with $10 \%$ (v:v) $\mathrm{HNO}_{3}$ was used between each sample. Furthermore, care was taken to run the samples in order of potential increasing concentrations to help minimize between sample carryover/memory effects (starting from snow followed by top/intermediate ice, seawater, brine, and bottom ice). All samples were handled with care using standard trace metal work precautions (gloves and sleeves) inside a portable class-100 laminar flow hood under a flowing stream of HEPA-filtered air. Instrument drift was periodically monitored between each set of samples using the 5-ppb calibration standard as a quality control solution. Data were blank corrected by subtracting an average of at least three acidified UHP blanks. Finally, the average DFe detection limit from the five-day-instrument run was calculated as $0.001 \mathrm{ppb}(0.02 \mathrm{nM} ; \mathrm{n}=15 ; 3 \mathrm{x}$ the standard deviation of the acidified UHP blank for each day of analysis). Analysis of certified reference material prepared in 10\% in-house seawater (NASS6, National Research Council Canada) was conducted in parallel with field samples. A mean Fe value of $0.423 \pm 0.02 \mu \mathrm{g} / \mathrm{L}(\mathrm{n}=3)$ was found, in good agreement with the certified (indicative) value of $0.493 \pm 0.05 \mu \mathrm{g} / \mathrm{L}$. Colloidal Fe fraction (cFe) was calculated as the difference between the DFe and sFe concentrations.

\subsubsection{Particulate Metals}

Polycarbonate filters with retained PFe and procedural filter blanks were digested using strong ultrapure acids to ensure complete digestion of the most refractory particles (Bowie et al., 2010). Firstly, a mixture of 250- $\mu \mathrm{l} 12 \mathrm{M} \mathrm{HCl}, 250-\mu \mathrm{l} 16 \mathrm{M} \mathrm{HNO}_{3}$, and 500- $\mu \mathrm{l} 29 \mathrm{M} \mathrm{HF}$ (Seastar Baseline, Choice Analytical) was added to each $15-\mathrm{ml}$ Teflon ${ }^{\circledR}$ perfluoroalkoxy vial (Savillex, USA) containing sample filters or blank filters. Vials were immediately closed and heated to $120^{\circ} \mathrm{C}$ for 12 hours over a Teflon ${ }^{\otimes}$-coated hot plate (SCP Science) inside a clean laboratory fume hood, followed by dry evaporation for 4 hours at $120^{\circ} \mathrm{C}$ after the vials were 
opened. The dried residues were then resuspended in 9.9-ml ultrapure $10 \%$ (v:v) $\mathrm{HNO}_{3}$ and $100 \mu \mathrm{l}$ of In solution (final concentration of $10 \mathrm{ppb}$ ). Five-ml subsamples were then transferred to 10-ml PP tubes before PFe quantification using SF-ICP-MS following the same procedures as outlined in section 2.4.4.1. The mean value for procedural digested acid blanks $(n=3)$ was $0.01 \pm 0.005 \mathrm{ppb}(0.2 \pm 0.1 \mathrm{nM})$. The limit of detection was calculated as three times the standard deviation of the procedural blank, determined as $0.015 \mathrm{ppb}$ $(0.27 \mathrm{nM})$. The same procedure and quality control were run for determination of other metals which purpose is described in the following section, listed as follows: aluminium (Al), barium (Ba), thorium (Th), strontium (Sr), and uranium (U).

\subsection{Statistical Analysis}

A linear mixed effects model was applied to the data set to investigate trends in the parameters of interest (DFe, sFe, cFe, PFe, PFe:DFe, Chla, and POC) over time. Before adjusting the model, a rank-based inverse transformation approach (rankit - Bishara \& Hittner, 2012) was applied to reduce the asymmetry, variability, and effects of discrepant observations; hence, normality could be assumed. The choice of a mixed model relies on the expected correlation between different ice sections, which was considered by a random effect of sections. Also included was the fixed effect of days, which was tested for significance in the regression models via a restricted maximum likelihood method. Potential correlations between $\mathrm{sFe}, \mathrm{cFe}$, $\mathrm{DFe}$, and $\mathrm{PFe}$ with other sea-ice physical and biogeochemical parameters were investigated using a Spearman correlation coefficient test due to the nonnormality observed in the data. For this test, two data sets were considered: all section (S1-S7) and only bottom sections (S6 and S7) along the whole study period. All analyses were performed using the R programming language (Version 3.3.1; R Core Team, 2013). The molar elemental ratios Fe:Al, Ba:Sr, and Th:U in the snow were used as a tracer of lithogenic sources (Sheraton \& Collerson, 1984; Wedepohl, 1995) and were obtained by the average particulate fraction concentration of the available samples.

\subsection{Fe Budget and Demand Calculation}

Based on the measurements of Fe concentration and sea-ice thickness from the sampled cores, a depthintegrated $\mathrm{DFe}, \mathrm{PFe}$, and TFe (DFe + PFe) inventory was calculated for each sampling day. The DFe inventory $\left(\mu \mathrm{mol} / \mathrm{m}^{2}\right)$ was determined by multiplying the concentrations of each ice core section by their section thickness and summing them up. In order to reduce a possible bias due to the intercore variability and to obtain a conservative balance between the ongoing physical and biological mediated changes in the iron pool and the potential input of dust associated to the punctual blizzard event observed at day 329, the Fe budget during the period under consideration was inferred by the following calculation. First, the inventory of the second half of the times series (median day 330-336) was subtracted by the inventory of the first half (median day 320-327). Next, this result was averaged with the budgets obtained from the median inventory of the first 2 days ( 320 and 325) and the last 2 days (days 333 and 336) and from the first (320) and last day (336). The potential Fe demand by sea-ice algae during the spring season was estimated by considering the average of the three highest POC concentrations at S7 (where autotrophs usually dominate), which were found on day 325, 327, and 333. Since around $90 \%$ of the POC was present in the lowermost layer (S7), Fe demand calculations were restricted for this layer as a proxy for the entire ice cores. Therefore, the maximum Fe demand of the ice was calculated by multiplying the average of the highest S7 POC concentrations by the literature average $\mathrm{Fe}: \mathrm{C}$ ratio for diatoms. Finally, the daily demand was determined by dividing the total demand by 90 , that is, the number of days in spring.

\section{3. Results}

\subsection{Sea-Ice Thermodynamics}

Sea-ice temperatures increased with ice-core depths, and over time, consistent with increasing air temperatures over the study period (Figure 3a). Brine volume fractions above 5\% during most of the time series indicate the permeable characteristic of the ice (Figure 3c). The highest Ra value (4.5) was observed on day 320 for the sea-ice top layer, and values close to zero were found in the bottom ice sections across most sampling days (Figure 3d). 
a) Temperature $\left({ }^{\circ} \mathrm{C}\right)$

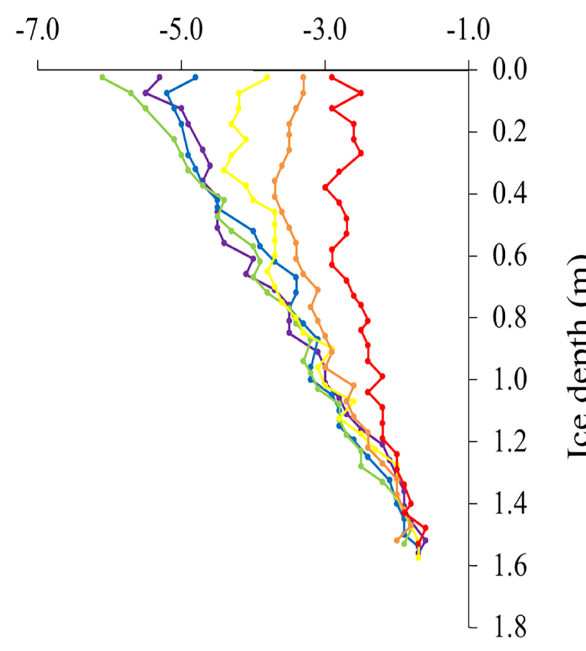

c) Brine volume (\%)

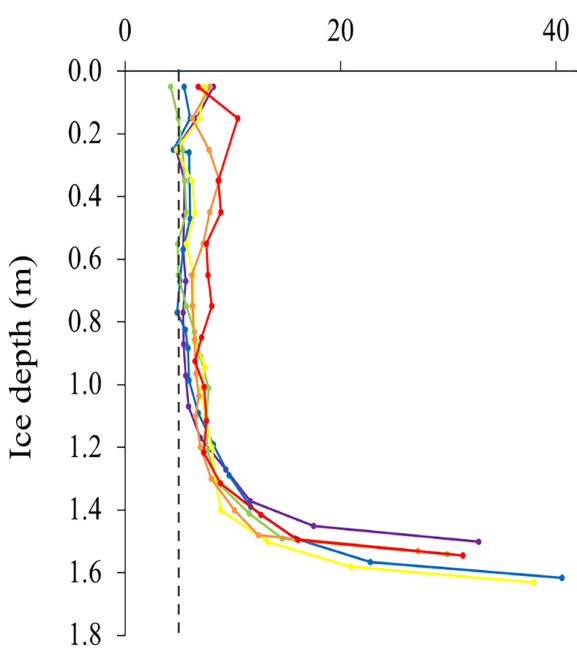

b) Salinity (psu)

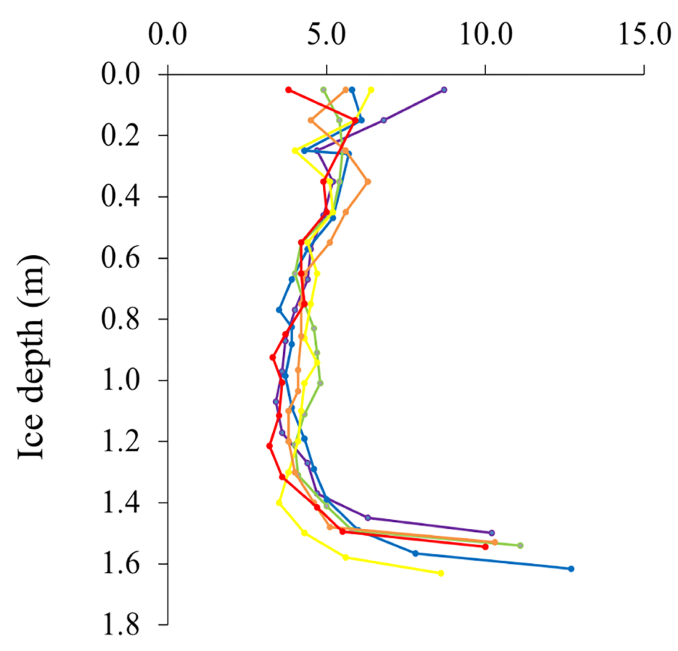

d) Rayleigh number ( $\mathrm{Ra})$

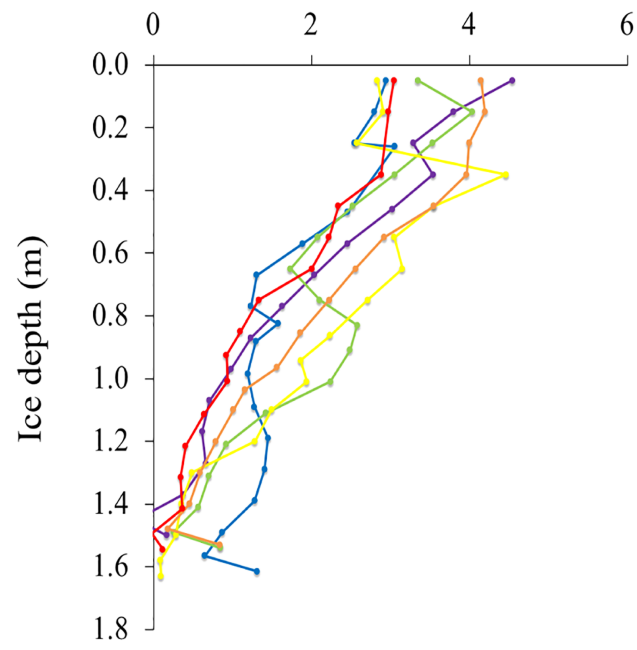

$$
\begin{array}{llllll}
-320 & -325 & -327 & -330 & -333 & -336
\end{array}
$$

Figure 3. (a) Vertical profiles of sea-ice temperature, (b) bulk-salinity, (c) calculated brine volume with the theoretical 5\% threshold for sea-ice permeability shown as dashed line, and (d) Rayleigh numbers ( $\mathrm{Ra}$ ) for each sampling day. The Ra expresses the ratio between the negative buoyancy in the brines and dissipation. Greater Ra numbers indicate a higher propensity for brine convection to occur.

\subsection{Vertical Distribution of Soluble, Colloidal, and Particulate Fe}

Despite the marked heterogeneity of the Fe distribution, DFe and PFe concentrations in sea ice were up to an order of magnitude higher than under ice water concentrations. Soluble, DFe, and PFe concentrations measured in the snow, sea ice, brine, and seawater are summarized in Table 1. A detailed description of values for each day and ice section is available through the link in section 6 .

The average depth-integrated iron inventories (days 320-336) for DFe, sFe, cFe, and PFe were 8.4 \pm 3.0 , $1.8 \pm 0.4,6.6 \pm 2.8$, and $38.3 \pm 29.0 \mu \mathrm{mol} / \mathrm{m}^{2}$, respectively. The cFe fraction represented approximately $75 \%$ of the integrated dissolved fraction, accounting for roughly $20 \%$ of the integrated TFe. Soluble and DFe for S5 on days 327, 330, and 333 showed distinct high outlier values when compared to the 
Table 1

Summary Statistics for Fe Fractions and Biological Parameters Averaged for the Whole Time Series

\begin{tabular}{|c|c|c|c|c|c|c|c|c|c|}
\hline \multirow[b]{2}{*}{ Medium } & \multicolumn{4}{|c|}{ Iron fractions } & \multicolumn{5}{|c|}{ Biology } \\
\hline & $\begin{array}{l}\mathrm{sFe} \\
(\mathrm{nM})\end{array}$ & $\begin{array}{c}\mathrm{cFe} \\
(\mathrm{nM})\end{array}$ & $\mathrm{DFe}(\mathrm{nM})$ & $\begin{array}{l}\mathrm{PFe} \\
(\mathrm{nM})\end{array}$ & $\begin{array}{c}\text { PFe:DFe (nM: } \\
\text { nM) }\end{array}$ & $\begin{array}{c}\text { Chla }(\mu \mathrm{g} / \\
\mathrm{L})\end{array}$ & POC $(\mu \mathbf{M})$ & $\begin{array}{l}\text { PON } \\
(\mu \mathrm{M})\end{array}$ & $\begin{array}{r}\text { POC:PON } \\
(\mu \mathrm{M}: \mu \mathbf{M})\end{array}$ \\
\hline $\begin{array}{l}\text { Snow } \\
\text { All sea ice (S1-S7) }\end{array}$ & $0.4 \pm 0.4$ & $19.1 \pm 13.9$ & $19.5 \pm 13.6$ & $1,630 \pm 2,350$ & $83.5 \pm 136$ & & $10.0 \pm 4.6$ & $0.5 \pm 0.3$ & $19.3 \pm 2.3$ \\
\hline Min. & 0.1 & 0.6 & 1.0 & 2.1 & 0.1 & 0.1 & 13.7 & 1.0 & 6.2 \\
\hline Max. & 17.1 & 46.8 & 63.8 & 416 & 30.9 & 240 & 3,270 & 435 & 45.1 \\
\hline Mean & 2.1 & 5.5 & 7.5 & 47.2 & 7.9 & 36.4 & 303 & 31.6 & 11.5 \\
\hline SD & 3.7 & 7.6 & 10.7 & 84.2 & 8.4 & 81.9 & 752 & 87.1 & 6.7 \\
\hline $\begin{array}{l}\text { Sea ice without bottom } \\
\quad \text { ice }\end{array}$ & $0.6 \pm 0.4$ & $3.3 \pm 2.2$ & $3.9 \pm 2.1$ & $20.6 \pm 25.2$ & $7.4 \pm 8.9$ & $1.0 \pm 0.8$ & $22.6 \pm 5.8$ & $2.2 \pm 0.7$ & $11.4 \pm 4.5$ \\
\hline $\begin{array}{l}\text { S6 }+S 7 \text { (bottom sea } \\
\quad \text { ice) }\end{array}$ & $5.3 \pm 5.5$ & $10.4 \pm 12.0$ & $15.7 \pm 16.6$ & $119 \pm 130$ & $9.0 \pm 7.6$ & $127 \pm 114$ & $1,000 \pm 1,170$ & $105 \pm 142$ & $11.7 \pm 11.2$ \\
\hline $\begin{array}{l}\text { S7 (including skeletal } \\
\text { layer) }\end{array}$ & $9.5 \pm 4.8$ & $15.1 \pm 16.0$ & $24.5 \pm 20.3$ & $176 \pm 163$ & $7.1 \pm 4.9$ & $223 \pm 38.4$ & $1,950 \pm 920$ & $205 \pm 141$ & $7.2 \pm 0.9$ \\
\hline Deep brine & $1.8 \pm 0.5$ & $6.9 \pm 3.3$ & $8.6 \pm 3.7$ & $12.5 \pm 7.0$ & $1.8 \pm 1.4$ & $1.4 \pm 0.6$ & $30.8 \pm 23.8$ & $65.8 \pm 150$ & $5.7 \pm 3.1$ \\
\hline Seawater $0 \mathrm{~m}$ & $1.3 \pm 2.2$ & $4.3 \pm 2.2$ & $5.6 \pm 1.5$ & $56.2 \pm 80.3$ & $10.7 \pm 14.7$ & $0.2 \pm 0.1$ & $14.0 \pm 13.0$ & $1.9 \pm 2.1$ & $8.1 \pm 3.1$ \\
\hline Seawater $3 \mathrm{~m}$ & $0.4 \pm 0.2$ & $3.6 \pm 1.5$ & $4.0 \pm 1.6$ & $5.6 \pm 4.6$ & $1.6 \pm 1.2$ & $0.2 \pm 0.1$ & $4.4 \pm 1.8$ & $0.7 \pm 0.3$ & $7.1 \pm 1.7$ \\
\hline Seawater $10 \mathrm{~m}$ & $0.4 \pm 0.2$ & $3.4 \pm 0.6$ & $4.3 \pm 1.2$ & $4.4 \pm 4.3$ & $1.3 \pm 1.5$ & $0.1 \pm 0.1$ & $4.3 \pm 1.4$ & $0.6 \pm 0.3$ & $6.9 \pm 1.0$ \\
\hline
\end{tabular}

neighboring sections and all top and intermediate layer values. We suspect that possible contamination could have occurred during the melting process of the S5 sections on these days since the same bucket was used; therefore, they were discarded for statistical analysis. Dissolved and PFe concentrations were generally high in the snowpack (Table 1 ), with markedly high values $(>1 \mu \mathrm{M})$ for PFe found on days 330, 333, and 336. Grey ash-like deposits were observed on the snow filters on these days. The average snow particulate Fe:Al, Ba:Sr, and Th:U molar ratios were $0.48(0.46-0.53, \mathrm{n}=6), 1.8(1.5-2.1, \mathrm{n}=5)$, and $2.6(1.0-3.0, \mathrm{n}=5)$, respectively.

Average concentrations for DFe, $\mathrm{sFe}, \mathrm{cFe}$, and PFe in seawater (SW3 and SW10) from all stations were $2.1 \pm$ $1.4,2.3 \pm 0.1,5.5 \pm 1.1$, and $2.4 \pm 4.3 \mathrm{nM}$, respectively. Values for SW0 were not considered here in order to obtain a more realistic picture of the Fe profile of the water column without the interference of localized fluctuations from the bottom ice.

\subsection{Temporal Distribution of Soluble, Colloidal, and Particulate Fe}

Davis data show that there was a decrease in bulk sea-ice DFe concentration from day 320 to 336 when all ice layers (S1-S7) are considered ( $\mathrm{p}<0.05)$. Both soluble and colloidal fraction (and consequently, total DFe) had a similar behavior over time, with increasing basal and decreasing surface and internal concentrations (Figures $4 \mathrm{~b}-4 \mathrm{~d}$ ). The mean $\mathrm{sFe}, \mathrm{cFe}$, and $\mathrm{DFe}$ concentrations from the upper and intermediate ice layers (S1-S5) declined from $1.2 \pm 0.1,10.3 \pm 14.5$, and $9.6 \pm 1.5 \mathrm{nM}$ on day 320 to $0.7 \pm 0.3,1.8 \pm 0.2$, and $2.2 \pm$ $0.8 \mathrm{nM}$ on day 336, respectively. Bottom ice (S6-S7) sFe, cFe, and DFe concentrations rose from $3.6 \pm 0.7$, $4.6 \pm 1.6$, and $8.2 \pm 2.6 \mathrm{nM}$ on day 320 to $6.8 \pm 8.7,8.3 \pm 8.8$, and $15.1 \pm 17.5 \mathrm{nM}$ on day 336 , respectively. In contrast, an increasing trend in the bulk sea-ice PFe (S1-S7) was observed for day 325, 330, 333, and 336 in relation to the first day ( $\mathrm{p}<0.01$ ). Mean PFe concentration increased from $8.9 \mathrm{nM}$ on day 320 to $70.3 \mathrm{nM}$ on day 336, peaking at day $330(112 \mathrm{nM})$. There is evidence of an accumulation of PFe also in the upper-middle layers of the ice (S1-S5) where the concentration increased from $4.5 \pm 1.5 \mathrm{nM}$ on the first day to $20.6 \pm 17.5 \mathrm{nM}$ on the last day. Overall, Davis sea ice lost $0.3 \pm 0.1 \mu \mathrm{mol} \cdot \mathrm{m}^{-2} \cdot$ day $^{-1}$ of DFe and 0.3 $\pm 0.1 \mu \mathrm{mol} \cdot \mathrm{m}^{-2} \cdot \mathrm{day}^{-1}$ of $\mathrm{cFe}$, while Fe was kept relatively constant $\left(0.004 \pm 0.02 \mu \mathrm{mol} \cdot \mathrm{m}^{-2} \cdot \mathrm{day}^{-1}\right)$. Particulate Fe increased by $2.6 \pm 0.7 \mu \mathrm{mol} \cdot \mathrm{m}^{-2}$. day ${ }^{-1}$ over the same period (see section 2.6 for budget calculation). The comparison between the first and second half of the time series (before and after the blizzard event) highlights the marked gain of PFe (Figure 5d). During this time, average seawater DFe concentration decreased from $5.2 \pm 1.1$ to $3.1 \pm 0.6 \mathrm{nM}(\mathrm{n}=12 ; \mathrm{p}<0.01)$, while seawater PFe concentration increased from $3.4 \pm 5.0$ to $6.6 \pm 3.0 \mathrm{nM}(\mathrm{n}=12$; no statistical difference) . 


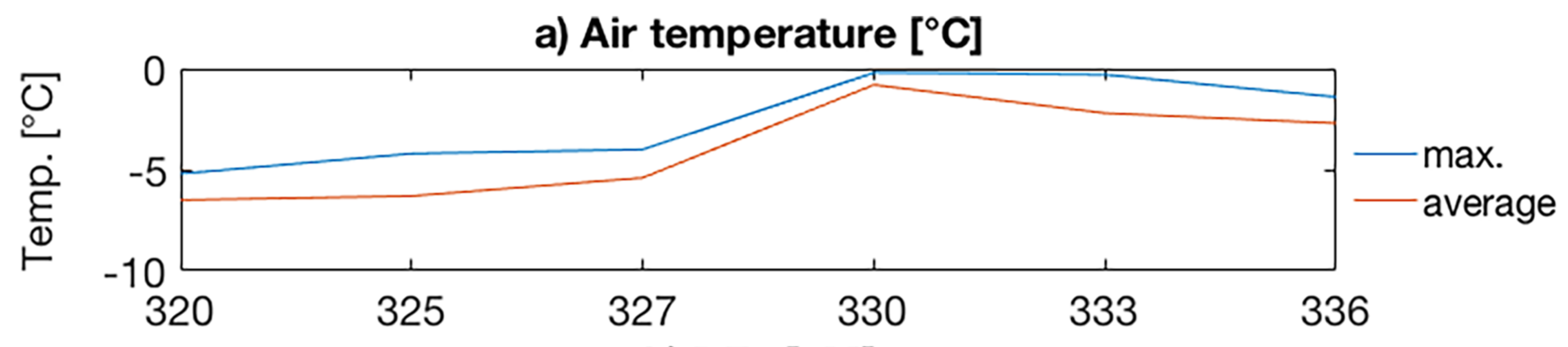

b) DFe [nM]

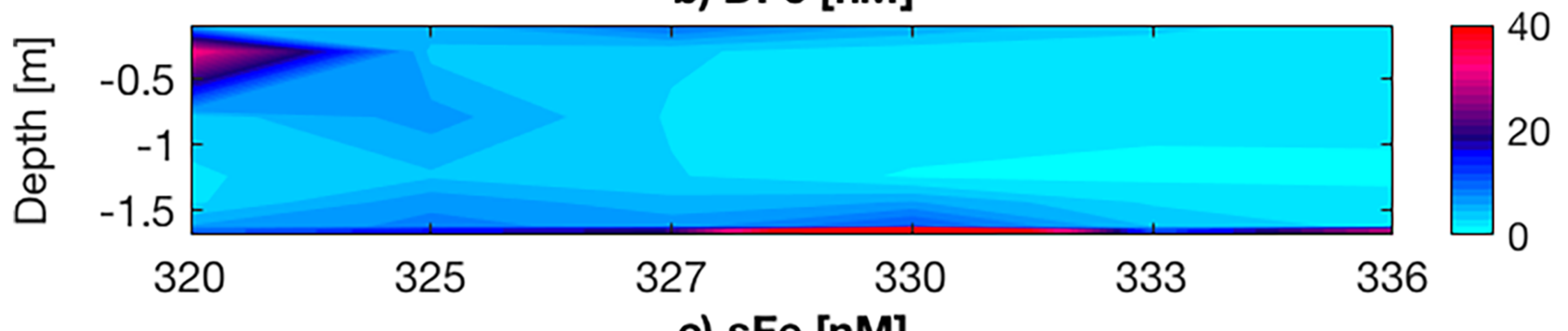

c) $\mathrm{sFe}[\mathrm{nM}]$

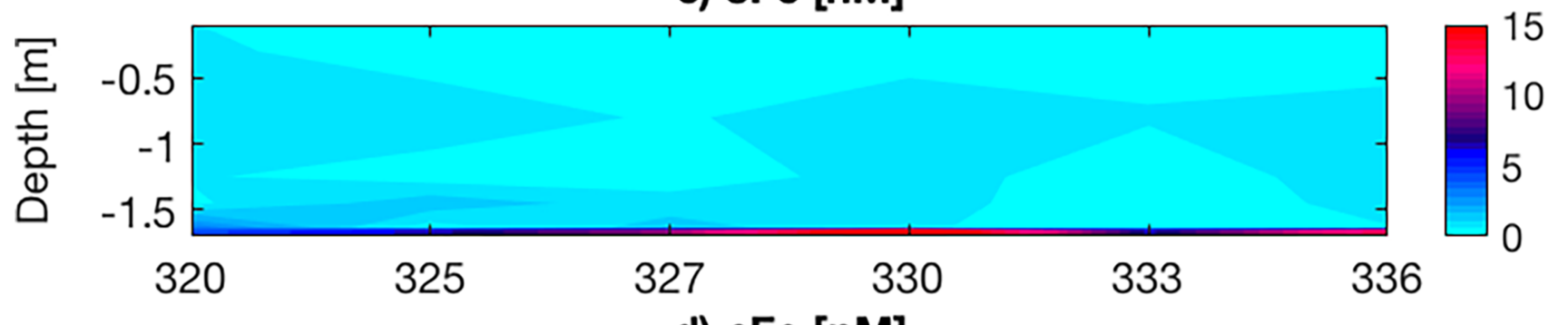

d) $\mathrm{cFe}[\mathrm{nM}]$

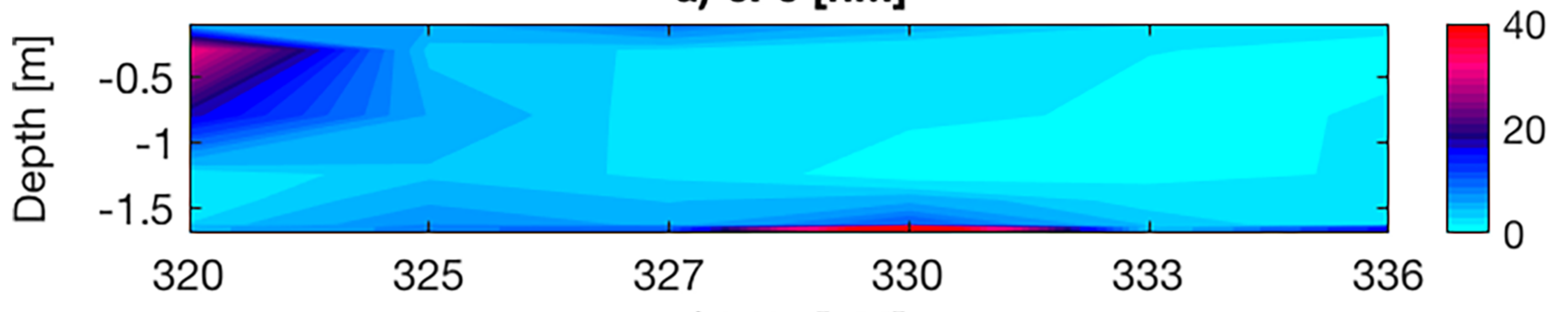

e) PFe [nM]

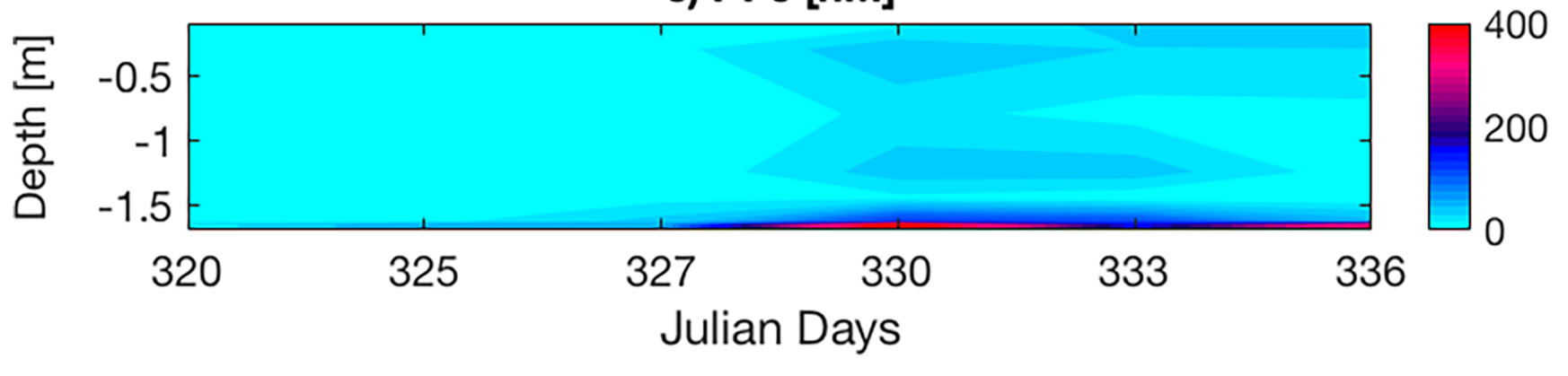

Figure 4. (a) Maximum and average daily air temperatures. Contour maps showing the temporal evolution of (b) dissolved (DFe), (c) soluble (sFe), (d) colloidal $(\mathrm{cFe})$, and (e) particulate ( $\mathrm{PFe}$ ) sea-ice iron fractions. 

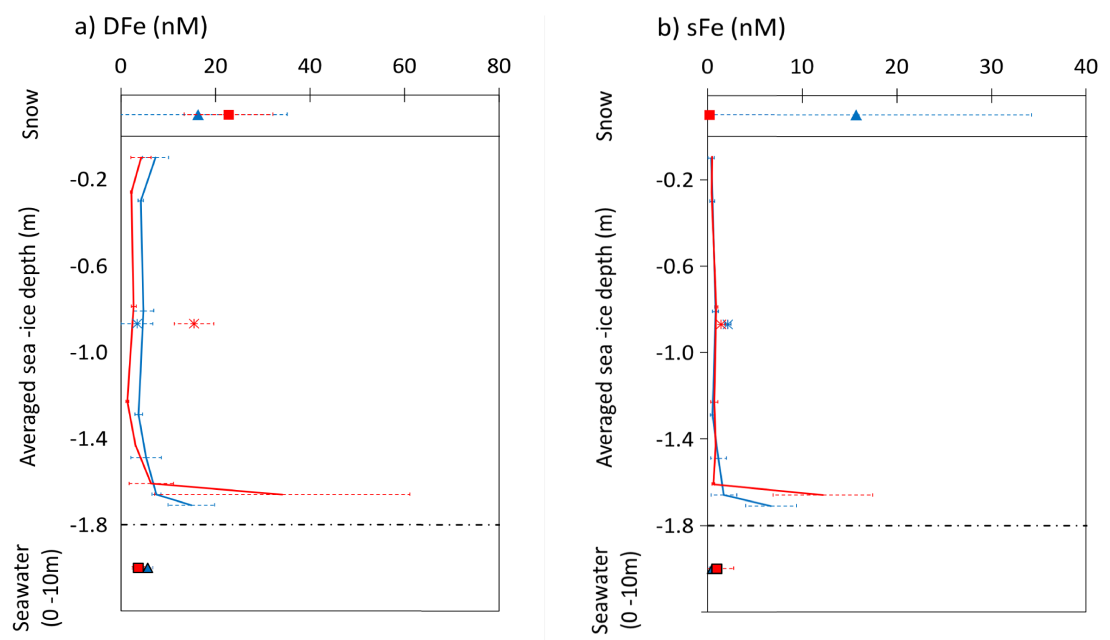

-sFe (before) - ice
-sFe (after) - ice
* sFe (before) - deep brine
* sFe (after) - deep brine
sFe (before) - snow
- sFe (after) - snow
sFe (before) - SW
- sFe (after) - SW

c) cFe (nM)

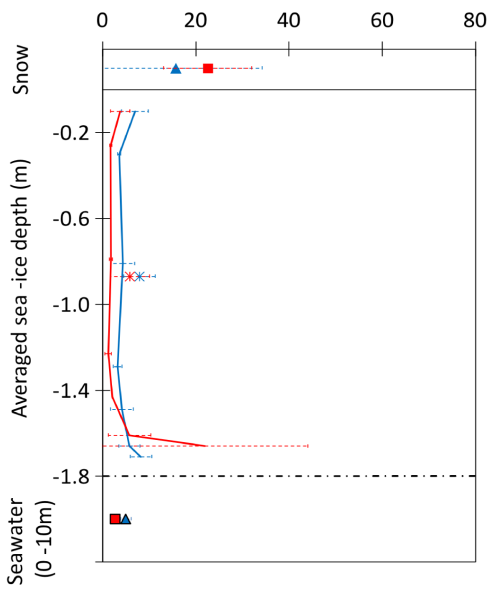

e) Chla ( $\mu \mathrm{g} / \mathrm{L})$ - log transformed

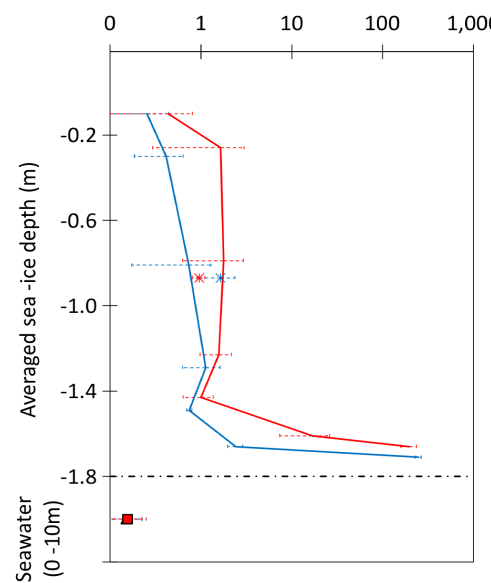

d) PFe (nM) - log transformed

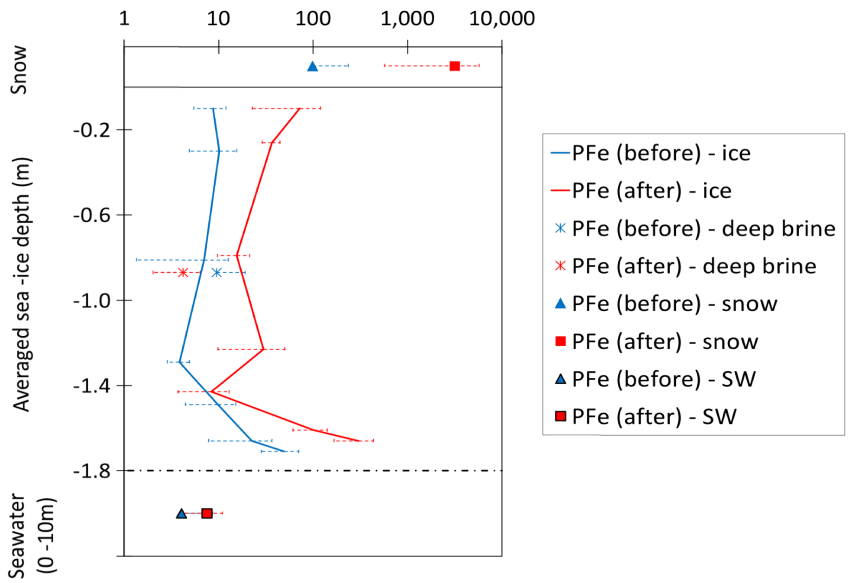

f) POC ( $\mu \mathrm{M})$ - log transformed

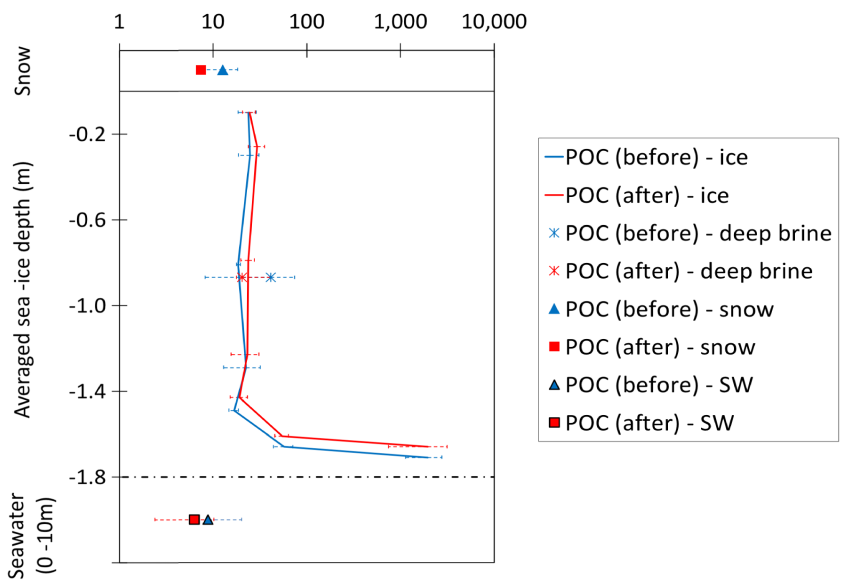

Figure 5. Vertical profiles of DFe, sFe, $\mathrm{cFe}, \mathrm{PFe}, \mathrm{Chl}$, and POC in sea ice before and after the blizzard event. Values were averaged for 320-327 (blue line) and 330-336 (red line). Standard deviations are represented by the horizontal bar. Also shown are values for snow, "deep brine," and under-ice seawater samples (expressed as mean values for SW0, SW1, and SW10 samples). 
Finally, a significant increase in the PFe:DFe ratio (nM:nM) over time was also observed $(\mathrm{p}<0.01)$. The mean PFe:DFe was $7.9 \pm 8.4$, increasing from $1.4 \pm 0.8$ on day 320 to $11.8 \pm 7.6$ on the last day. At day 320 , PFe represented around $45 \%$ of the total Fe content in sea ice, increasing to over $90 \%$ on day 336. Both the soluble and colloidal fraction percentage decreased during the time series, with the reduction in the colloidal fraction more pronounced than in the soluble fraction.

\subsection{Sea-Ice Biogeochemistry and Correlations with Fe Fractions}

High concentrations of Chla were maintained throughout the time series, particularly in S7, where values were up to three orders of magnitude higher than the mean Chla concentration of the underlying seawater (Table 1). Although a statistically significant temporal trend in total Chla could not be observed, an increase in Chla is evidenced when both half-period averages are compared (Figure 5e). A significant increase in POC over time was detected for day 325, 330, 333, and 336 ( $\mathrm{p}<0.01)$. The POC and PON vertical profiles followed the same pattern as the Chla, with higher values in the bottom sections (link to data available in section 6).

A strong correlation of PFe with POC and PON $(\rho>0.7, p<0.01)$ and some evidence of correlation of sFe with Chl $a$ were observed $(\rho=0.6, p<0.01)$. A moderate correlation of sFe with temperature $(\rho=0.7)$, salinity ( $\rho=0.6$ ), and brine volume ( $\rho=0.6$ ) was also found. There was no evidence of a correlation between DFe and PFe for all the sections analyzed together and only a moderate one for the bottom ice $(\rho=0.6, p<0.05)$.

\section{Discussion}

\subsection{How Thermodynamics Control Fe Distribution in Fast Ice During Late Spring}

During this study we could observe a transitional sea-ice stage characterized by temperatures evolving toward isothermal conditions and decreasing brine salinities (Figure 3). At the beginning of the time series (day 320), the lower air temperature maintained the ice surface colder than the bottom and a resulting C-shape salinity profile (Figure 3a and $3 \mathrm{~b}$ ). The season progressed, and ice surface temperatures reached values above $-5^{\circ} \mathrm{C}$ for the first time on day 325. Although the Ra number did not exceed any theoretical threshold for brine convection during this study (typically of 7; Notz \& Worster, 2008), higher Ra numbers were observed in the top layers of the ice (where cold, salty, and dense brine sits) on day 320 (Figure 3d). This suggests a potential instability and propensity for brine convection to occur and could explain the transfer of the most of the DFe pool from the upper layers of the ice (S1, S2) to the bottom ice (S6, S7) between day 320 and 325 (Figure 4b). The loss of brine by convection was also evidenced by a decrease in sea-ice surface salinity. On day 325, the Ra gradient (the difference between top and bottom) was already the lowest of the time series; thus, brine drainage is expected to be the main process driving the vertical transfer of Fe from thereon.

The lack of correlation of $\mathrm{PFe}, \mathrm{DFe}$, and $\mathrm{cFe}$ with brine volume suggests that part of the Fe was retained in the ice despite brine movement (Lannuzel et al., 2016). This is further evidenced by the fact the Fe concentrations measured in sack-hole brines were much lower than the theoretical brine concentrations calculated for all $\mathrm{Fe}$ fractions $([\mathrm{Fe}] \mathrm{br}=[\mathrm{Fe}] / \Phi \mathrm{br}$, where $[\mathrm{Fe}]$ is the concentration of $\mathrm{Fe}$ in the bulk sea-ice sample and $\Phi b r$ is the brine fraction). Interestingly, the mean ratio between theoretical and measured concentrations for the soluble fraction $(5 \mathrm{nmol} / \mathrm{nmol})$ was half that obtained for the colloidal fraction $(10 \mathrm{nmol} / \mathrm{nmol})$, suggesting a distinct behaviour between these size fractions. Soluble Fe exhibited a moderate correlation with temperature $(\rho=0.7)$, salinity $(\rho=0.6)$ and brine volume $(\rho=0.6)$, further indicating some conservative behavior between this fraction and the ice thermodynamics. Particulate Fe was also impoverished in the sack-hole brine compared to bulk sea ice when theoretical brine PFe concentrations were calculated, with no correlation with salinity, brine volume, or DFe. Although a high contribution of lithogenic sources to the particulate fraction might have masked any possible correlation between PFe and DFe, these results corroborate previous field observations (van de Merwe, Lannuzel, Bowie, Nichols, \& Meiners, 2011) showing that the PFe and cFe fractions might be more susceptible to physical entrapment in the brine channel system than the truly sFe fractions.

\subsection{Sea-Ice Biology: Estimating the Fe Demand by Ice Algae}

The enhanced autotrophic activity in the internal layers of the ice, evidenced by increasing Chla concentrations, combined with a peak of Chla in the upper $3 \mathrm{~m}$ of the water column on day 330 (from $0.1 \mu \mathrm{g} / \mathrm{L}$ on day 327 to $0.3 \mu \mathrm{g} / \mathrm{L}$ on day 330), suggests that both sea-ice algae and phytoplankton benefited from the supply of DFe from surface and interior ice layers. The high Chla concentrations in the lowermost ice sections, where 
conditions of light, space, and nutrient availability are favorable for growth, point toward the dominance of autotrophic activity at this time of the year (Arrigo et al., 2017; Meiners et al., 2018). Archer et al. (1996) reported heterotrophic protozoa were approximately twice as abundant in the sea-ice interior than in bottom ice near Davis Station during late spring-summer 1994. In our study, differences in the POC:PON and Chla: POC ratios observed between S7 and the layers above also suggest a predominant autotrophic bottom and heterotrophic ice interior.

Assuming that the majority of POC in both seawater and bottom sea ice consist of autotroph cells (as inferred from the POC:PON ratios) and using the average Fe:C uptake ratio of $35 \mu \mathrm{mol}$ :mol for marine diatoms (Sarthou et al., 2005), one can estimate the maximum biological Fe demand during spring. Up to $52 \mathrm{nmol} \cdot \mathrm{m}^{-2}$. day ${ }^{-1}$ of Fe is required to sustain Davis fast ice (and water column) productivity. During the study period, DFe concentration in seawater $(1-10 \mathrm{~m})$ decreased by approximately $2 \mu \mathrm{mol} \cdot \mathrm{m}^{-2} \cdot \mathrm{day}^{-1}$. Even if we assume the bottomice communities used Fe exclusively from the seawater via ice-seawater exchanges, the daily loss of seawater DFe greatly exceeded the ice biological demand (and negligible consumption from the phytoplankton). A higher $\mathrm{Fe}: \mathrm{C}$ uptake ratio by ice algae compared to pelagic phytoplankton could partially explain this difference; sea-ice algae could have evolved to less efficient use of the abundant Fe present in sea ice. In fact, it has been demonstrated that Fe and silicate colimit diatom growth in the Southern Ocean (Brzezinski et al., 2005; de La Rocha et al., 2000; Franck et al., 2000, 2003; Hoffmann et al., 2007). Considering the predominance of this type of algae group in the ice, a higher silicate requirement per unit of carbon synthesized could, consequently, mean a higher demand for Fe as well. This said, an unlikely and much higher $\mu \mathrm{mol}: \mathrm{mol} \mathrm{Fe}: \mathrm{C}$ biological uptake is needed to fully explain the total removal of DFe observed in the seawater, assuming the stability of this fraction in the water.

A more plausible answer for the observed mismatch between the primary producers' Fe demand and the seawater DFe decrease could be related to the short residence time of DFe in seawater. The relatively high initial DFe concentration in the seawater on day 320 could come from the sea ice; the changes in sea-ice temperature and permeability observed can promote the flushing of salts and DFe (Lannuzel et al., 2013). Within the seawater, this new input of DFe can rapidly be converted to less soluble forms of Fe in the particulate range via binding with unsaturated algae-produced exopolymeric substances (EPS) favoring aggregation onto settling particles or directly precipitated as particulate oxides (Decho \& Gutierrez, 2017; Schoemann et al., 1998). In contrast to the DFe trend in the seawater, there is evidence of an increase in the PFe concentration indicating that part of the DFe drainaged to the water might have indeed been adsorbed/converted into PFe. The dominance of autotrophic over heterotrophic processes in the surface water, assumed by the POC:PON ratio (6.7) close to the Redfield ratio of 6.6 for algae uptake (Redfield et al., 1963), would keep the seawater $\mathrm{DFe}$ concentration low due to the lack of conversion of PFe into DFe via recycling. It is worth mentioning that potential advection of new water masses (e.g., tidal cycles) with different physicochemical properties could also have affected the seawater results, masking a clear interaction between the sea-ice and seawater Fe pools (Smith et al., 1984).

\subsection{Sources of Iron to Davis Fast Ice}

The fast ice off Davis lost approximately $0.3 \pm 0.14 \mu \mathrm{mol} \cdot \mathrm{m}^{-2} \cdot$ day $^{-1}$ of DFe during the time series $(3.6 \pm 1.1$ $\mu \mathrm{mol} / \mathrm{m}^{2}$ over the entire period). This suggests the ice itself could potentially supply all the Fe needed $\left(52 \mathrm{nmol} \cdot \mathrm{m}^{-2} \cdot \mathrm{day}^{-1}\right)$ for the local sea-ice algae and phytoplankton to grow. On the other hand, during the same period, bulk-ice PFe and total Fe $(\mathrm{TFe}=\mathrm{DFe}+\mathrm{PFe})$ in Davis fast ice increased on average by $2.6 \pm 0.7$ and $2.3 \pm 0.6 \mu \mathrm{mol} \cdot \mathrm{m}^{-2} \cdot$ day $^{-1}$, respectively. This represents a $\sim 50 \%$ increase in the TFe inventory during the time series. The conversion of DFe to PFe via biological uptake would only account for a maximum of $5 \%$ of this budget. Therefore, an external input of PFe must be considered. In the next paragraphs, potential sources of Fe to Davis land-fast ice are discussed.

4.3.1. Sediments and Tides: The Influence of Coastal Proximity on the Distribution of Iron in Fast Ice.

Benthic diffusion and resuspension of sediments has been associated with high productivity rates in coastal areas of Antarctica and is suggested as the main pathway to fuel marine productivity on the Antarctic shelf (de Jong et al., 2012). Micromolar DFe concentrations can be found in sediments due to the anoxic reduction and dissolution of the particulate phase (Sachs et al., 2009). The shallow bathymetry of the studied area and the labile characteristics of local surface sediments of predominant biogenic nature would also favor 
Table 2

Reported Fe Concentrations (nM) in Land-Fast Ice, Snow on Sea Ice, and Under-Ice Seawater From Different Areas of the Southern Ocean/Antarctica.

\begin{tabular}{|c|c|c|c|c|c|}
\hline Sample type & Season & $\mathrm{DFe}(\mathrm{nM})$ & $\mathrm{PFe}(\mathrm{nM})$ & Region & Reference \\
\hline \multicolumn{6}{|l|}{ Snow } \\
\hline & $\begin{array}{l}\text { Spring/ } \\
\text { summer }\end{array}$ & $5.2-37.7$ & $9.0-6,090$ & Prydz Bay, East Antarctica & This study \\
\hline & Spring & $0.2-1.1$ & $1.1-12.0$ & East Antarctica & van der Merwe, Lannuzel, Bowie, Nichols, and Meiners (2011) \\
\hline & Winter/spring & $0.9-7.1$ & $2.3-101$ & East Antarctica & van der Merwe, Lannuzel, Bowie, and Meiners (2011) \\
\hline & Summer & $112-2,410$ & $243-10,900$ & Ross Sea, McMurdo Sound & de Jong et al. (2013) \\
\hline & Winter/spring & $1.0-6.5$ & $2.1-15.0$ & East Antarctica & Lannuzel et al. (2007) \\
\hline & $\begin{array}{l}\text { Spring/ } \\
\text { summer }\end{array}$ & $0.7-3.2$ & $7.8-14.0$ & Weddell Sea & Lannuzel et al. (2008) \\
\hline \multicolumn{6}{|l|}{ Fast ice } \\
\hline & $\begin{array}{l}\text { Spring/ } \\
\text { summer }\end{array}$ & $1.0-63.8$ & $2.1-416$ & Prydz Bay, East Antarctica & This study \\
\hline & Spring & $0.8-2.1$ & $7.5-215$ & East Antarctica & van der Merwe, Lannuzel, Bowie, Nichols, and Meiners (2011) \\
\hline & Winter/spring & $2.1-81.0$ & $40.4-6,830$ & East Antarctica & van der Merwe, Lannuzel, Bowie, and Meiners (2011) \\
\hline & Summer & $2.2-109$ & $9.0-1,850$ & Ross Sea, McMurdo Sound & de Jong et al. (2013) \\
\hline & Summer & $1.1-6.0$ & $26.0-1,160$ & Terra Nova Bay, Ross Sea & Grotti et al. (2005) \\
\hline \multicolumn{6}{|c|}{ Under-ice seawater } \\
\hline & $\begin{array}{l}\text { Spring/ } \\
\text { summer }\end{array}$ & $2.5-6.6$ & $0.2-11.8$ & Prydz Bay, East Antarctica & This study \\
\hline & Spring & $0.1-2.6$ & $0.1-2.9$ & East Antarctica & van der Merwe, Lannuzel, Bowie, Nichols, and Meiners (2011) \\
\hline & Winter/spring & $1.5-3.7$ & $11.0-60.0$ & East Antarctica & van der Merwe, Lannuzel, Bowie, and Meiners (2011) \\
\hline & Summer & $0.3-3.7$ & $1.1-20.0$ & Ross Sea, McMurdo Sound & de Jong et al. (2013) \\
\hline & Summer & $0.7-1.5$ & $28.0-45.0$ & Terra Nova Bay, Ross Sea & Grotti et al. (2005) \\
\hline & Winter/spring & $1.1-4.5$ & $<\mathrm{dl}-4.4$ & East Antarctica & Lannuzel et al. (2007) \\
\hline & $\begin{array}{l}\text { Spring/ } \\
\text { summer }\end{array}$ & $0.7-1.7$ & $0.4-4.0$ & Weddell Sea & Lannuzel et al. (2008) \\
\hline
\end{tabular}

bacterial activity (Dunbar et al., 1989). De Jong et al. (2012) described the presence of a permanent nepheloid layer at the seafloor associated with resuspension processes enriched in leachable PFe which could represent an upfront source of high levels of bioavailable Fe. Even the lower range of marine sediment fluxes reported by the author $\left(1.3 \mu \mathrm{mol} \cdot \mathrm{m}^{-2}\right.$. day $\left.{ }^{-1}\right)$ could fully explain the DFe concentrations found in sea ice and seawater throughout the present study. During autumn, the mobilization of this source, driven by the presence of ocean surface winds and a deeper mixed layer, could favor the incorporation of Fe-rich sediments into the ice. Convection driven by barotropic currents (tidal and density) and vertical diffusion could further pump sediments into the porous sections of the bottom sea ice at the ice water interface (Hodgkinson et al., 1991; Nunes Vaz \& Lennon, 1996). Eventually, this Fe pool can be supplied to the ice algae and phytoplankton communities in spring, when environmental conditions favor primary productivity but surface mixing are weakened by the presence of sea ice.

Sea-ice DFe concentrations from this study were close to those reported from fast ice in the Ross Sea during summer by de Jong et al. (2013) and in East Antarctica during winter/spring (van der Merwe, Lannuzel, Bowie, \& Meiners, 2011). Common to these sites was the proximity to the coast (less than $2 \mathrm{~km}$ ). DFe reported here were generally higher than those observed by Grotti et al. (2005) in the Ross Sea during summer (Table 2$)$, possibly due to the deeper bathymetry ( $450 \mathrm{~m})$ of their study site. Our Fe values were also higher than those measured in East Antarctic fast ice, collected approximately $75 \mathrm{~km}$ away from the coast (van der Merwe, Lannuzel, Bowie, Nichols, \& Meiners, 2011). Interestingly, PFe concentrations at Davis were in general lower compared to the past studies. This discrepancy could result from a range of factors. Differences in the type of sea ice (columnar versus granular), timing of ice formation, presence or absence of platelet ice, age of the ice (first/multiyear ice), and stage of the season (spring versus summer), for example, could all lead to different concentrations of PFe incorporated from sedimentary sources (de Jong et al., 2013).

4.3.2. Snow and Dust: Can Ice-Free Areas Impact on Fe Concentrations in Fast Ice?

Snowpack PFe values measured during the first half of the time series at Davis (days 320-327, 9.0-255 nM) were similar to those previously observed off Casey Station (van der Merwe, Lannuzel, Bowie, \& Meiners, 2011; van der Merwe, Lannuzel, Bowie, Nichols, \& Meiners, 2011). However, snow PFe values observed during the second half of our study (days 330-336, 1.2-6.1 $\mu \mathrm{M}$ ) are much higher and only comparable to 
those reported from McMurdo Sound, Ross Sea (de Jong et al., 2013). Snowfall and snowdrift associated with strong winds (see Figure S1) halfway through the time series led to PFe concentrations $>1 \mu \mathrm{M}$ in the snowpack at day 330, 333, and 336. Hourly recorded air temperature data from Davis Station showed positive air temperatures were reached for the first time on day 329 (Figure 4a). This surface warming may have led to the percolation of Fe-rich particles through the melting snowpack, leading to the sharp PFe increase observed in the ice below on day 330. This input can be translated into $80 \%$ of PFe added to the sea ice between the first and second half of the time series and could be explained by the percolation of only $5 \%$ of the snow PFe.

The question is "Where is this high PFe in snow coming from?". The proximity to extensive ice-free land as common geographic characteristic could explain the high snow PFe observed near Davis and McMurdo. The Davis sampling site was surrounded by ice-free rocks: Vestfold Hills in the south, the largest rocky ice-free land in East Antarctica, and three major islands (Anchorage, Trigwell, and Futtler Island) in the north. A satellite image obtained during springtime shows the possible influence of this dust source to the area (Figure 1b), where northeasterly winds draw a dust plume to the ice offshore from the Vestfold Hills and surrounding islands. To validate this satellite observation, elemental molar ratios measured in snow samples were compared to literature values from the continental crust and Vestfold Hills rock samples. The average snow Fe:Al molar ratio of 0.5 obtained from Davis snow is consistent with previous Fe:Al ratio estimates of $\sim 0.4$ for the upper continental crust obtained during different geological surveys (Gao et al., 1998; Taylor \& McLennan, 1985; Wedepohl, 1995). Similarly, the snow Ba:Sr ratio of 1.8 from this study also falls within the range of 0.9-2.5 for the upper and bulk continental crust and is close to values found in the predominant rock composition of the Vestfold Hills, listed as follows: felsic tonalite (0.9 to 1.4), mafic granulite (0.6 to 3.1), and biotite-garnet-quartz-feldspar gneisses ( 2.0), which vary along the Vestfold Hills (Sheraton \& Collerson, 1984). The observed Davis snow Th:U ratio (2.6) was also consistent with Th:U values from the abundant tonalities found in the Mossel and Crooked Lake gneisses (2.0 and 4.0), two major lithogenic units of the Vestfold Hills (Sheraton \& Collerson, 1984; Sheraton et al., 1984). Therefore, assuming the absence of seawater infiltration into the snow (as indicated by the low snow salinity value) and disregarding any negligible contribution from long-range atmospheric aerosol deposition during the period under consideration, the overall high concentration of $\mathrm{PFe}$ in the snow can be plausibly linked to natural dust input from the surrounding land, as also suggested by the satellite imagery. In this context, we can calculate the PFe flux from local dust sources. Coastal dust was responsible for a flux of $374 \pm 146 \mu \mathrm{mol} \cdot \mathrm{m}^{-2}$. day ${ }^{-1}$ of PFe over the blizzard event. The same can be translated into an average flux of $8.3 \pm 3.3 \mu \mathrm{mol} \cdot \mathrm{m}^{-2}$. day ${ }^{-1}$ of dust PFe into Davis land-fast sea ice, assuming three months of the spring season.

Dust is a lithogenic and therefore a highly refractory source of Fe. Once added to sea ice or seawater, lithogenic Fe can undergo photochemical and biologically mediated processes that increase its bioavailability (Frew et al., 2006; Hassler \& Schoemann, 2009). These processes can become especially relevant considering the magnitude of the dust flux observed. Besides affecting the amount of Fe input to sea ice, snow PFe can supplement the Fe released from melting sea ice, potentially extending the duration of the Fe fertilization from the event. Global-scale biogeochemical models have assigned the fractional solubility of natural $\mathrm{Fe}$ aerosols within the range of 1-10\% (Archer \& Johnson, 2000; Fung et al., 2000; Gao, 2003; Gregg et al., 2003; Moore et al., 2004; Moore \& Doney, 2007). Using this solubility range and dust flux of $8.3 \mu \mathrm{mol} \cdot \mathrm{m}^{-2} \cdot \mathrm{day}^{-1}$, windblown dust could deliver 0.08 to $0.8 \mu \mathrm{mol} \cdot \mathrm{m}^{-2}$. day ${ }^{-1}$ of DFe to the sea ice and seawater during springtime. It is worth noting that this flux could be lower or higher given that Fe solubility in dust particles is still a highly debated topic (Chen et al., 2006; Mackie et al., 2006; Mahowald et al., 2009; Zhu et al., 1997). Edwards and Sedwick (2001), for example, reported Fe solubility of 30\% in Antarctic snow, while other researchers have argued that almost all aeolian Fe might be bioavailable, depending on the timescale, ligands complexation, and acquisition mechanisms from the biological community (Gledhill \& Buck, 2012; Mahowald et al., 2009; Weber et al., 2005). The dissolution of lithogenic PFe within the snow could explain why the ice sFe concentrations were maintained constant through time even considering evidence of brine movement. Part of this $\mathrm{sFe}$ is expected to be rapidly converted into cFe (Wu et al., 2001), which could then bind to EPS and be adsorbed onto cell surfaces. The concentration of cFe would still decrease, as observed here, not only due to the loss of this fraction to the seawater via gravity drainage but also because cell coated cFe-EPS is retained during filtration. Interestingly, the mean $\mathrm{SFe}: \mathrm{PFe}$ ratio obtained in snow samples from the first half of the time series $\left(5 \times 10^{-2} \pm 7 \times 10^{-2}\right)$, before the snowstorm on day 329 , was three orders 
of magnitude greater than the mean sFe:PFe from the second half $\left(7.5 \times 10^{-5} \pm 5 \times 10^{-5}\right)$ of the study. This indicates that the interaction between snow, which can carry atmospheric acids such as sulfate and organic acids, and the dust may increase Fe solubility in snow, given enough time for this process to occur. The relevance of this symbiotic interaction is evidenced by studies which have shown that atmospheric aerosol particles have much higher Fe solubility (up to 80\%; Baker \& Jickells, 2006; Johansen et al., 2000) than soil purely. Once deposited onto the snowpack, the Fe dissolution from refractory particles could be further aided by photochemical reactions in the snowpack, taking advantage of its upfront exposition to the sunlight. Photoreduction of $\mathrm{Fe}^{+3}$ to $\mathrm{Fe}^{+2}$ can enhance its solubility and bioavailability (Barbeau \& Moffett, 2000). Therefore, even though most of the Fe found in the Davis snowpack is likely from local dust and not from other types of atmospheric aerosol particles (desert dust/combustion) carried during wet deposition (snow), the sFe:PFe results suggest an important interaction between snow and dust (soil) favoring the solubilization of Fe. Although the processes discussed above are potentially relevant for the first part of the time series, the short observation window after day 329 restricted our chances to observe the same Fe solubilization in surface snow during the second part. Clearly, measurements using relevant sieving and chemical leaching techniques are needed to deliver a uniform assessment on Fe solubility from lithogenic sources under varying atmospheric conditions.

\subsubsection{Flux From Other Sources}

The average and range of under-ice seawater DFe concentrations in this study were higher than previously observed under land-fast and pack ice (Table 2). This could not only be related to the shallow bathymetry of the area $(20 \mathrm{~m})$ and contribution from sea ice but also to the proximity of nearby ice shelves, lateral transport, as well as recycling processes. When the sea ice starts to consolidate during autumn, convective processes driven by the brine rejection contribute to the vertical mixing of water. At this time of the year, seawater is also enriched in Fe from the melting of the surrounding AIS and WIS. Herraiz-Borreguero et al. (2016) found concentrations of DFe in the marine ice of the AIS up to four orders of magnitude higher than those typical of Southern Ocean surface waters, which could fertilize waters $300 \mathrm{~km}$ away from the meltwater source. The potential influx of bioavailable Fe into Prydz Bay waters due to the common presence of icebergs could also have an important impact on the mobilization of sediments and mechanical mixing/upwelling of the water column, also dragging considerable amount of terrigenous material (Arrigo et al., 2008; Duprat et al., 2016; Raiswell et al., 2008; Smith et al., 2007). Lateral advection associated with the westerly current along the coast and deeper intrusive water masses originating from the Antarctic Circumpolar Current can also sustain a constant influx of new stock of Fe into the area (Nunes Vaz \& Lennon, 1996). Finally, biotic mechanisms such as grazing by protozoa and recycling by higher trophic levels have been proposed to regenerate bioavailable Fe in the seawater providing a secondary source of Fe to coastal fast ice (Nicol et al., 2010; Ratnarajah et al., 2014; Schmidt et al., 2016).

\subsection{Estimating the Potential Primary Production in East Antarctica From Fast-Ice Melting}

The combined sea-ice and snow median inventory of $13.9-\mu \mathrm{mol} / \mathrm{m}^{2} \mathrm{DFe}$ and $252-\mu \mathrm{mol} / \mathrm{m}^{2} \mathrm{PFe}$ for the study period could represent a flux to the seawater of approximately 0.5 and $8.4 \mu \mathrm{mol} \cdot \mathrm{m}^{-2}$. day $^{-1}$, respectively; assuming a period of 30 days for the complete release of both fractions (Lannuzel et al., 2008). This ice $\mathrm{DFe}$ flux is higher than the estimate of $0.3 \mu \mathrm{mol} \cdot \mathrm{m}^{-2} \cdot$ day $^{-1}$ for pack ice around East Antarctica (Lannuzel et al., 2010), 0.34 and $0.25 \mu \mathrm{mol} \cdot \mathrm{m}^{-2}$. day $^{-1}$ for ice floes in the Bellingshausen Sea (de Jong et al., 2015), and $0.05-0.3 \mu \mathrm{mol} \cdot \mathrm{m}^{-2} \cdot$ day $^{-1}$ obtained for land-fast sea ice in McMurdo Sound, Ross Sea (de Jong et al., 2013). Based on our Fe concentration measurements and considering that a strip of approximately $20-\mathrm{km}$ wide first-year fast ice along the $\sim 1,200 \mathrm{~km}$ eastern shore of Prydz Bay (Ingrid Christensen to Queens Mary Coast) is formed every winter (Fraser et al., 2012), $0.6 \pm 0.2$ tons/day DFe is expected to be released on the east coast of Prydz Bay during the melting season. The transport of coastal ice floes into offshore waters could represent, therefore, an important source of this essential element to Fe-depleted waters. Under favorable conditions of light and macronutrient availability, this "new" Fe input could potentially produce about $170 \mathrm{mgC} \cdot \mathrm{m}^{-2} \cdot$ day $^{-1}$ of biomass (disregarding any regenerative DFe process associated with the microbial loop, recycling from higher trophic levels and/or other sources of DFe), which is comparable to the production estimated as $200 \mathrm{mgC} \cdot \mathrm{m}^{-2}$.day ${ }^{-1}$ for early December (Arrigo et al., 2008) for the whole of Antarctic shelf waters. Our estimate suggests that Fe does not limit primary production in the coastal areas of the South Indian sector of Antarctica. 


\section{Conclusions}

Results from this study indicate that primary production in East Antarctic fast ice is not Fe-limited during late spring/early summer. The contribution of ice-free land areas on the fast ice Fe pool is also highlighted. The magnitude of this Fe source will become more pronounced as we expect ice-free areas to increase in Antarctica. A higher input of dust to the major system of polynyas in Prydz Bay via fast ice melting, and associated ocean physics and biological dynamics, could represent an important vector of potentially bioavailable Fe to Antarctic open waters. Foreseen changes in the prevailing precipitation regime toward higher snowfall in coastal East Antarctica are also expected to impact the biogeochemical and physical properties of the fast ice. This could also lead to a phenological mismatch between nutrient availability and ideal light conditions if the timing and duration of Fe delivery relative to the nutrient uptake capacity of algae communities are altered. For all that, the potential fertilization of the Southern Ocean via sea-ice melting should be directly impacted by changes in the coastal areas. Further studies are needed to assess the impact of enhances lithogenic Fe input to Antarctic fast ice and beyond.

\section{Acknowledgments}

This work was cofunded by the Australian Government Cooperative Research Centres Programme through the Antarctic Climate and Ecosystems Cooperative Research Centre (ACE CRC), the Australian Antarctic Science (AAS) project no. 4291 and 4298, the Australian Research Council's Special Research Initiative for Antarctic Gateway Partnership (Project ID SR140300001) and the Vrije Universiteit Brussel internal funding in the framework of Strategic Research Plan "Tracers of Past and Present Global Changes." The authors thank the two reviewers for their comments which greatly improved the manuscript. Data supporting the analyses and conclusions here presented can be accessed at the Australian Antarctic Data Centre website (https://data.aad.gov.au/ metadata/records/AAS_4291_2016_ seaice).

\section{References}

Arar, E. J., \& Collins, G. B. (1997). Method 445.0 [electronic resource]: In vitro determination of chlorophyll a and pheophytin a in marine and freshwater algae by fluorescence. [Cincinnati, OH]: United States Environmental Protection Agency, Office of Research and Development, National Exposure Research Laboratory, [1997].

Archer, D. E., \& Johnson, K. (2000). A model of the iron cycle in the ocean. Global Biogeochemical Cycles, 14(1), 269-279. https://doi.org/ 10.1029/1999GB900053

Archer, S. D., Leakey, R. J. G., Burkill, P. H., Sleigh, M. A., \& Appleby, C. J. (1996). Microbial ecology of sea ice at a coastal Antarctic site: Community composition, biomass and temporal change. Marine Ecology Progress Series, 135(1-3), 179-195. https://doi.org/10.3354/ meps135179

Arrigo, K. R., van Dijken, G. L., Alderkamp, A.-C., Erickson, Z. K., Lewis, K. M., Lowry, K. E., et al. (2017). Early spring phytoplankton dynamics in the Western Antarctic Peninsula. Journal of Geophysical Research: Oceans, 122, 9350-9369. https://doi.org/10.1002/ $2017 \mathrm{jc} 013281$

Arrigo, K. R., van Dijken, G. L., \& Bushinsky, S. (2008). Primary production in the Southern Ocean, 1997-2006. Journal of Geophysical Research, 113, C08004. https://doi.org/10.1029/2007jc004551

Arrigo, K. R., van Dijken, G. L., \& Strong, A. L. (2015). Environmental controls of marine productivity hot spots around Antarctica. Journal of Geophysical Research: Oceans, 120, 5545-5565. https://doi.org/10.1002/2015jc010888

Baker, A. R., \& Jickells, T. D. (2006). Mineral particle size as a control on aerosol iron solubility. Geophysical Research Letters, 33, L17608. https://doi.org/10.1029/2006gl026557

Barbeau, K., \& Moffett, J. W. (2000). Laboratory and field studies of colloidal iron oxide dissolution as mediated by phagotrophy and photolysis. Limnology and Oceanography, 45, 827-835. https://doi.org/10.4319/lo.2000.45.4.0827

Benner, R. (2011). Loose ligands and available iron in the ocean. Proceedings of the National Academy of Sciences, $108(3), 893-894$. https://doi.org/10.1073/pnas.1018163108

Bishara, A. J., \& Hittner, J. B. (2012). Testing the significance of a correlation with nonnormal data: Comparison of Pearson, Spearman, transformation, and resampling approaches. Psychological Methods, 17(3), 399-417. https://doi.org/10.1037/a0028087

Blain, S., Quéguiner, B., Armand, L., Belviso, S., Bombled, B., Bopp, L., et al. (2007). Effect of natural iron fertilization on carbon sequestration in the Southern Ocean. Nature, 446(7139), 1070-1074. https://doi.org/10.1038/nature05700

Borer, P. M., Sulzberger, B., Reichard, P., \& Kraemer, S. M. (2005). Effect of siderophores on the light-induced dissolution of colloidal iron (III) (hydr)oxides. Marine Chemistry, 93(2-4), 179-193. https://doi.org/10.1016/j.marchem.2004.08.006

Bowie, A. R., Townsend, A. T., Lannuzel, D., Remenyi, T. A., \& van der Merwe, P. (2010). Modern sampling and analytical methods for the determination of trace elements in marine particulate material using magnetic sector inductively coupled plasma-mass spectrometry. Analytica Chimica Acta, 676(1-2), 15-27. https://doi.org/10.1016/j.aca.2010.07.037

Boyd, P. W., Jickells, T., Law, C. S., Blain, S., Boyle, E. A., Buesseler, K. O., et al. (2007). Mesoscale iron enrichment experiments 1993-2005: Synthesis and future directions. Science, 315(5812), 612-617. https://doi.org/10.1126/science.1131669

Brzezinski, M. A., Jones, J. L., \& Demarest, M. S. (2005). Control of silica production by iron and silicic acid during the Southern Ocean iron experiment (SOFeX). Limnology and Oceanography, 50(3), 810-824. https://doi.org/10.4319/lo.2005.50.3.0810

Chen, M., Dei, R. C. H., Wang, W. X., \& Guo, L. D. (2003). Marine diatom uptake of iron bound with natural colloids of different origins. Marine Chemistry, 81(3-4), 177-189. https://doi.org/10.1016/S0304-4203(03)00032-X

Chen, Y., Street, J., \& Paytan, A. (2006). Comparison between pure-water- and seawater-soluble nutrient concentrations of aerosols from the Gulf of Aqaba. Marine Chemistry, 101(1-2), 141-152. https://doi.org/10.1016/j.marchem.2006.02.002

Cox, G. F. N., \& Weeks, W. F. (1988). Numerical simulations of the profile properties of undeformed first-year sea ice during the growth season. Journal of Geophysical Research, 93(C10). https://doi.org/10.1029/JC093iC10p12449

de Jong, J., Schoemann, V., Lannuzel, D., Croot, P., de Baar, H., \& Tison, J.-L. (2012). Natural iron fertilization of the Atlantic sector of the Southern Ocean by continental shelf sources of the Antarctic Peninsula. Journal of Geophysical Research, 117, G01029. https://doi.org/ $10.1029 / 2011$ jg001679

de Jong, J., Schoemann, V., Maricq, N., Mattielli, N., Langhorne, P., Haskell, T., \& Tison, J. L. (2013). Iron in land-fast sea ice of McMurdo Sound derived from sediment resuspension and wind-blown dust attributes to primary productivity in the Ross Sea, Antarctica. Marine Chemistry, 157, 24-40. https://doi.org/0.1016/j.marchem.2013.07.001, https://doi.org/10.1016/j.marchem.2013.07.001

De Jong, J. T. M., Stammerjohn, S. E., Ackley, S. F., Tison, J.-L., Mattielli, N., \& Schoemann, V. (2015). Sources and fluxes of dissolved iron in the Bellingshausen Sea (West Antarctica): The importance of sea ice, icebergs and the continental margin. Marine Chemistry, 177, 518-535. https://doi.org/10.1016/j.marchem.2015.08.004

De La Rocha, C. L., Hutchins, D. A., Brzezinski, M. A., \& Zhang, Y. (2000). Effects of iron and zinc deficiency on elemental composition and silica production by diatoms. Marine Ecology Progress Series, 195, 71-79. https://doi.org/10.3354/meps195071 
Decho, A. W., \& Gutierrez, T. (2017). Microbial extracellular polymeric substances (EPSs) in ocean systems. Frontiers in Microbiology, 8 , 922. https://doi.org/10.3389/fmicb.2017.00922

Dunbar, R. B., Leventer, A. R., \& Stockton, W. L. (1989). Biogenic sedimentation in Mcmurdo Sound, Antarctica. Marine Geology, 85(2-4), 155-179. https://doi.org/10.1016/0025-3227(89)90152-7

Duprat, L. P. A. M., Bigg, G. R., \& Wilton, D. J. (2016). Enhanced Southern Ocean marine productivity due to fertilization by giant icebergs . Nature Geoscience, 9(3), 219-221. https://doi.org/10.1038/ngeo2633

Edwards, R., \& Sedwick, P. (2001). Iron in East Antarctic snow: Implications for atmospheric iron deposition and algal production in Antarctic waters. Geophysical Research Letters, 28(20), 3907-3910. https://doi.org/10.1029/2001gl012867

Franck, M., Brzezinski, M. A., Coale, K. H., \& Nelson, D. M. (2000). Iron and silicic acid concentrations regulate Si uptake north and south of the polar frontal zone in the Pacific sector of the Southern Ocean. Deep Sea Research Part II: Topical Studies in Oceanography, 47(15-16), 3315-3338. https://doi.org/10.1016/s0967-0645(00)00070-9

Franck, V. M., Bruland, K. W., Hutchins, D. A., \& Brzezinski, M. A. (2003). Iron and zinc effects on silicic acid and nitrate uptake kinetics in three high-nutrient, low-chlorophyll (HNLC) regions. Marine Ecology Progress Series, 252, 15-33. https://doi.org/10.3354/meps252015

Fraser, A. D., Massom, R. A., Michael, K. J., Galton-Fenzi, B. K., \& Lieser, J. L. (2012). East Antarctic landfast sea ice distribution and variability, 2000-2008. Journal of Climate, 25(4), 1137-1156. https://doi.org/10.1175/Jcli-D-10-05032.1

Frew, R. D., Hutchins, D. A., Nodder, S., Sanudo-Wilhelmy, S., Tovar-Sanchez, A., Leblanc, K., et al. (2006). Particulate iron dynamics during Fe cycle in subantarctic waters southeast of New Zealand. Global Biogeochemical Cycles, 20, GB1S93. https://doi.org/10.1029/ $2005 \mathrm{gb002558}$

Fung, I. Y., Meyn, S. K., Tegen, I., Doney, S. C., John, J. G., \& Bishop, J. K. B. (2000). Iron supply and demand in the upper ocean. Global Biogeochemical Cycles, 14(1), 281-295. https://doi.org/10.1029/1999gb900059

Gao, S., Luo, T. C., Zhang, B. R., Zhang, H. F., Han, Y. W., Zhao, Z. D., \& Hu, Y. K. (1998). Chemical composition of the continental crust as revealed by studies in East China. Geochimica et Cosmochimica Acta, 62(11), 1959-1975. https://doi.org/10.1016/s0016-7037(98)00121-5

Gao, Y. (2003). Aeolian iron input to the ocean through precipitation scavenging: A modeling perspective and its implication for natural iron fertilization in the ocean. Journal of Geophysical Research, 108(D7), 4221. https://doi.org/10.1029/2002JD002420

Gerringa, L. J. A., Alderkamp, A.-C., Laan, P., Thuróczy, C.-E., de Baar, H. J. W., Mills, M. M., et al. (2012). Iron from melting glaciers fuels the phytoplankton blooms in Amundsen Sea (Southern Ocean): Iron biogeochemistry. Deep Sea Research Part II: Topical Studies in Oceanography, 71-76, 16-31. https://doi.org/10.1016/j.dsr2.2012.03.007

Gledhill, M., \& Buck, K. N. (2012). The organic complexation of iron in the marine environment: A review. Frontiers in Microbiology, 3, 69. https://doi.org/10.3389/fmicb.2012.00069

Google Earth Pro 7 V.3.2.5776 (2015). Davis Station, Antarctica. 68 34' 36" S, 7758' 03" E, eye alt 8.7 km. Image Landsat/Copernicus. DigitalGlobe 2019. http://www.earth.google.com [July 20, 2019]

Gregg, W. W., Ginoux, P., Schopf, P. S., \& Casey, N. W. (2003). Phytoplankton and iron: Validation of a global three-dimensional ocean biogeochemical model. Deep Sea Research Part II: Topical Studies in Oceanography, 50(22-26), 3143-3169. https://doi.org/10.1016/j. dsr2.2003.07.013

Grotti, M., Soggia, F., Ianni, C., \& Frache, R. (2005). Trace metals distributions in coastal sea ice of Terra Nova Bay, Ross Sea, Antarctica. Antarctic Science, 17(2), 289-300. https://doi.org/10.1017/S0954102005002695

Hassler, C. S., \& Schoemann, V. (2009). Bioavailability of organically bound Fe to model phytoplankton of the Southern Ocean. Biogeosciences Discussions, 6(10), 2281-2296. https://doi.org/10.5194/bg-6-2281-2009

Herraiz-Borreguero, L., Lannuzel, D., van der Merwe, P., Treverrow, A., \& Pedro, J. B. (2016). Large flux of iron from the Amery Ice Shelf marine ice to Prydz Bay, East Antarctica. Journal of Geophysical Research: Oceans, 121, 6009-6020. https://doi.org/10.1002/ $2016 \mathrm{jc} 011687$

Hodgkinson, R., Colman, R.S., Robb, M.S., \& Williams, R. (1991). Current meter moorings in the region of Prydz Bay, Antarctica, 1987. Research notes 81, Antarctic Division, Kingston, Tasmania, Australia, p. 130.

Hoffmann, L. J., Peeken, I., \& Lochte, K. (2007). Co-limitation by iron, silicate, and light of three Southern Ocean diatom species. Biogeosciences Discussions, 4(1), 209-247. https://doi.org/10.5194/bgd-4-209-2007

Hudson, R. J. M., \& Morel, F. M. M. (1990). lron transport in marine phytoplankton: Kinetics of cellular and medium coordination reactions. Limnology and Oceanography, 35(5), 1002-1020. https://doi.org/10.4319/lo.1990.35.5.1002

Hudson, R. J. M., \& Morel, F. M. M. (1993). Trace-metal transport by marine microorganisms-Implications of metal coordination kinetics. Deep-Sea Research Part I: Oceanographic Research Papers, 40(1), 129-150. https://doi.org/10.1016/0967-0637(93)90057-A

Johansen, A. M., Siefert, R. L., \& Hoffmann, M. R. (2000). Chemical composition of aerosols collected over the tropical North Atlantic Ocean. Journal of Geophysical Research, 105(D12), 15277-15312. https://doi.org/10.1029/2000jd900024

Kraemer, S. M. (2004). Iron oxide dissolution and solubility in the presence of siderophores. Aquatic Sciences - Research Across Boundaries, 66(1), 3-18. https://doi.org/10.1007/s00027-003-0690-5

Kuma, K., \& Matsunaga, K. (1995). Availability of colloidal ferric oxides to coastal marine-Phytoplankton. Marine Biology, 122(1), 1-11. https://doi.org/10.1007/Bf00349272

Lannuzel, D., de Jong, J., Schoemann, V., Trevena, A., Tison, J. L., \& Chou, L. (2006). Development of a sampling and flow injection analysis technique for iron determination in the sea ice environment. Analytica Chimica Acta, 556(2), 476-483. https://doi.org/10.1016/ j.aca.2005.09.059

Lannuzel, D., Schoemann, V., de Jong, J., Chou, L., Delille, B., Becquevort, S., \& Tison, J. L. (2008). Iron study during a time series in the western Weddell pack ice. Marine Chemistry, 108(1-2), 85-95. https://doi.org/10.1016/j.marchem.2007.10.006

Lannuzel, D., Schoemann, V., de Jong, J., Pasquer, B., van der Merwe, P., Masson, F., et al. (2010). Distribution of dissolved iron in Antarctic sea ice spatial seasonal and interannual variability. Journal of Geophysical Research, 115, G03022. https://doi.org/10.1029/ 2009JG001031

Lannuzel, D., Schoemann, V., de Jong, J., Tison, J. L., \& Chou, L. (2007). Distribution and biogeochemical behavior of iron in the East Antarctic sea ice. Marine Chemistry, 106(1-2), 18-32. https://doi.org/10.1016/j.marchem.2006.06.010

Lannuzel, D., van der Merwe, P., Townsend, A. T., \& Bowie, A. R. (2014). Size fractionation of iron, manganese and aluminum in Antarctic fast ice reveals a lithogenic origin and low iron solubility. Marine Chemistry, 161, 47-56. https://doi.org/10.1016/j.marchem2014.02.006

Lannuzel, D., Vancoppenolle, M., van der Merwe, P., de Jong, J., Meiners, K. M., Grotti, M., et al. (2016). Iron in sea ice: Review and new insights. Elementa: Science of the Anthropocene, 4, 000130. https://doi.org/10.12952/journal.elementa.000130

Lannuzel, D., Schoemann, V., Dumont, I., Content, M., de Jong, J., Tison, J.-L., ... Becquevort, S. (2013). Effect of melting Antarctic sea ice on the fate of microbial communities studied in microcosms. Polar Biology, 36(10), 1483-1497. https://doi.org/10.1007/s00300-013-1368-7 
Lee, J. R., Raymond, B., Bracegirdle, T. J., Chades, I., Fuller, R. A., Shaw, J. D., \& Terauds, A. (2017). Climate change drives expansion of Antarctic ice-free habitat. Nature, 547(7661), 49-54. https://doi.org/10.1038/nature22996

Lis, H., Shaked, Y., Kranzler, C., Keren, N., \& Morel, F. M. (2015). Iron bioavailability to phytoplankton: An empirical approach. The ISME Journal, 9(4), 1003-1013. https://doi.org/10.1038/ismej.2014.199

Mackie, D. S., Peat, J. M., McTainsh, G. H., Boyd, P. W., \& Hunter, K. A. (2006). Soil abrasion and aeolian dust production: Implications for iron partitioning and solubility. Geochemistry, Geophysics, Geosystems, 7, Q12Q03. https://doi.org/10.1029/2006gc001404

Mahowald, N. M., Engelstaedter, S., Luo, C., Sealy, A., Artaxo, P., Benitez-Nelson, C., et al. (2009). Atmospheric iron deposition: Global distribution, variability, and human perturbations. Annual Review of Marine Science, 1, 245-278. https://doi.org/10.1146/annurev. marine.010908.163727

Martin, J. H. (1990). Glacial-interglacial $\mathrm{CO}_{2}$ change: The iron hypothesis. Paleoceanography, 5(1), 1-13. https://doi.org/10.1029/ PA005i001p00001

Martin, J. H., \& Fitzwater, S. E. (1988). Iron deficiency limits phytoplankton growth in the north-east Pacific subarctic. Nature, 331 , 341-343. https://doi.org/10.1038/331341a0

Martin, J. H., Gordon, R. M., \& Fitzwater, S. E. (1991). The case for iron. Limnology and Oceanography, 36(8), 1793-1802. https://doi.org/ 10.4319/lo.1991.36.8.1793

Meiners, K. M., Vancoppenolle, M., Carnat, G., Castellani, G., Delille, B., Delille, D., et al. (2018). Chlorophyll-a in Antarctic landfast sea ice: A first synthesis of historical ice core data. Journal of Geophysical Research: Oceans, 123, 8444-8459. https://doi.org/10.1029/ 2018jc014245

Millero, F. J. (1998). Solubility of Fe (III) in seawater. Earth and Planetary Science Letters, 154(1-4), 323-329. https://doi.org/10.1016/S0012$821 x(97) 00179-9$

Moore, J. K., \& Doney, S. C. (2007). Iron availability limits the ocean nitrogen inventory stabilizing feedbacks between marine denitrification and nitrogen fixation. Global Biogeochemical Cycles, 21, GB2001. https://doi.org/10.1029/2006GB002762

Moore, J. K., Doney, S. C., Glover, D. M., \& Fung, I. Y. (2001). Iron cycling and nutrient- limitation patterns in surface waters of the World Ocean. Deep Sea Research Part II: Topical Studies in Oceanography, 49(1-3), 463-507. https://doi.org/10.1016/s09670645(01)00109-6

Moore, J. K., Doney, S. C., \& Lindsay, K. (2004). Upper ocean ecosystem dynamics and iron cycling in a global three-dimensional model. Global Biogeochemical Cycles, 18, GB2001. https://doi.org/10.1029/2006GB002762

Morel, F. M. M., Kustka, A. B., \& Shaked, Y. (2008). The role of unchelated Fe in the iron nutrition of phytoplankton. Limnology and Oceanography, 53(1), 400-404. https://doi.org/10.4319/lo.2008.53.1.0400

NASA Earth Observing System Data and Information System (EOSDIS) (2018). Terra/MODIS true color image from Davis Station. Retrieved from https://worldview.earthdata.nasa.gov

Nicol, S., Bowie, A., Jarman, S., Lannuzel, D., Meiners, K. M., \& Van Der Merwe, P. (2010). Southern Ocean iron fertilization by baleen whales and Antarctic krill. Fish and Fisheries, 11(2), 203-209. https://doi.org/10.1111/j.1467-2979.2010.00356.x

Notz, D., \& Worster, M. G. (2008). In situ measurements of the evolution of young sea ice. Journal of Geophysical Research, 113, C03001. https://doi.org/10.1029/2007jc004333

Nunes Vaz, R. A., \& Lennon, G. W. (1996). Physical oceanography of the Prydz Bay region of Antarctic waters. Deep Sea Research Part I: Oceanographic Research Papers, 43(5), 603-641. https://doi.org/10.1016/0967-0637(96)00028-3

Raiswell, R., Benning, L. G., Tranter, M., \& Tulaczyk, S. (2008). Bioavailable iron in the Southern Ocean: The significance of the iceberg conveyor belt. Geochemical Transactions, 9(1). https://doi.org/10.1186/1467-4866-9-7

Ratnarajah, L., Bowie, A. R., Lannuzel, D., Meiners, K. M., \& Nicol, S. (2014). The biogeochemical role of baleen whales and krill in Southern Ocean nutrient cycling. PLoS One, 9(12). https://doi.org/10.1371/journal.pone.0114067

R Core Team (2013). R: A language and environment for statistical computing. R Foundation for Statistical Compluting, Viena, Austria. http://R-project.org/

Redfield, A. C., Ketchum, B. H., \& Richards, F. A. (1963). The influence of organisms on the composition of sea water. In M. N. Hill (Ed.), The Sea., 2. New York: Interscience Publishers.

Rintala, J. M., Piiparinen, J., Blomster, J., Majaneva, M., Müller, S., Uusikivi, J., \& Autio, R. (2014). Fast direct melting of brackish sea-ice samples results in biologically more accurate results than slow buffered melting. Polar Biology, 37(12), 1811-1822. https://doi.org/ 10.1007/s00300-014-10431563-1

Sachs, O., Sauter, E. J., Schlüter, M., Rutgers van der Loeff, M. M., Jerosch, K., \& Holby, O. (2009). Benthic organic carbon flux and oxygen penetration reflect different plankton provinces in the Southern Ocean. Deep Sea Research Part I: Oceanographic Research Papers, 56(8), 1319-1335. https://doi.org/10.1016/j.dsr.2009.02.003

Sarthou, G., Timmermans, K. R., Blain, S., \& Treguer, P. (2005). Growth physiology and fate of diatoms in the ocean: A review. Journal of Sea Research, 53(1-2), 25-42. https://doi.org/10.1016/j.seares.2004.01.007

Schmidt, K., Schlosser, C., Atkinson, A., Fielding, S., Venables, H. J., Waluda, C. M., \& Achterberg, E. P. (2016). Zooplankton Gut Passage Mobilizes Lithogenic Iron for Ocean Productivity. Current Biology, 26(19), 2667-2673. https://doi.org/10.1029/PA005i001p00001

Schoemann, V., de Baar, H. J. W., de Jong, J. T. M., \& Lancelot, C. (1998). Effects of phytoplankton blooms on the cycling of manganese and iron in coastal waters. Limnology and Oceanography, 43(7), 1427-1441. https://doi.org/10.4319/lo.1998.43.7.1427

Sedwick, P. N., Edwards, P. R., Mackey, D. J., Griffiths, F. B., \& Parslow, J. S. (1997). Iron and manganese in surface waters of the Australian subantarctic region. Deep-Sea Research Part I: Oceanographic Research Papers, 44(7), 1239-1253. https://doi.org/10.1016/S09670637(97)00021-6

Sheraton, J. W., Black, L. P., \& McCulloch, M. T. (1984). Regional geochemical and isotopic characteristics of high-grade metamorphics of the Prydz Bay area: The extent of proterozoic reworking of Archaean continental crust in East Antarctica. Precambrian Research, 26(2), 169-198. https://doi.org/10.1016/0301-9268(84)90043-3

Sheraton, W., \& Collerson, K. D. (1984). Archaean and proterozoic geological relationships in the Vestfold Hills-Prydz Bay area, Antarctica. Journal of Australian Geology \& Geophysics, 8, 19-128.

Smith, K. L., Robison, B. H., Helly, J. J., Kaufmann, R. S., Ruhl, H. A., Shaw, T. J., et al. (2007). Free-drifting icebergs: hot spots of chemical and biological enrichment in the Weddell Sea. Science, 317(5837), 478-482. https://doi.org/10.1126/science.1142834

Smith, N. R., Zhaoqian, D., Kerry, K. R., \& Wright, S. (1984). Water masses and circulation in the region of Prydz Bay, Antarctica. Deep Sea Research Part I: Oceanographic Research Papers, 31(9), 1121-1147. https://doi.org/10.1016/0198-0149(84)90016-5

Sullivan, C. W., Arrigo, K. R., McClain, C. R., Comiso, J. C., \& Firestone, J. (1993). Distributions of phytoplankton blooms in the Southern Ocean. Science, 262(5141), 1832-1837. https://doi.org/10.1126/science.262.5141.1832 
Sulzberger, B., Suter, D., Siffert, C., Banwart, S., \& Stumm, W. (1989). Dissolution of Fe (III)(Hydr)Oxides in Natural-Waters-Laboratory assessment on the kinetics controlled by surface coordination. Marine Chemistry, 28(1-3), 127-144. https://doi.org/10.1016/03044203(89)90191-6

Taylor, S. R., \& McLennan, S. M. (1985). The continental crust: Its composition and evolution. Geological Magazine, 122(06). https://doi.org/10.1017/s0016756800032167

van der Merwe, P., Lannuzel, D., Bowie, A. R., \& Meiners, K. M. (2011). High temporal resolution observations of spring fast ice melt and seawater iron enrichment in East Antarctica. Journal of Geophysical Research, 116, G03017. https://doi.org/10.1029/2010jg001628

van der Merwe, P., Lannuzel, D., Bowie, A. R., Nichols, C. A. M., \& Meiners, K. M. (2011). Iron fractionation in pack and fast ice in East Antarctica: Temporal decoupling between the release of dissolved and particulate iron during spring melt. Deep Sea Research Part II: Topical Studies in Oceanography, 58(9-10), 1222-1236. https://doi.org/10.1016/j.dsr2.2010.10.036

van der Merwe, P., Lannuzel, D., Nichols, C. A. M., Meiners, K., Heil, P., Norman, L., et al. (2009). Biogeochemical observations during the winter-spring transition in East Antarctic sea ice: Evidence of iron and exopolysaccharide controls. Marine Chemistry, 115(3-4), 163-175. https://doi.org/10.1016/j.marchem.2009.08.001

Vancoppenolle, M., Notz, D., Vivier, F., Tison, J., Delille, B., Carnat, G., et al. (2013). Technical note: On the use of the mushy-layer Rayleigh number for the interpretation of sea-ice-core data. The Cryosphere Discussions, 7(4), 3209-3230. https://doi.org/10.5194/tcd-73209-2013

Weber, L., Völker, C., Schartau, M., \& Wolf-Gladrow, D. A. (2005). Modeling the speciation and biogeochemistry of iron at the Bermuda Atlantic time-series study site. Global Biogeochemical Cycles, 19, GB1019. https://doi.org/10.1029/2004gb002340

Wedepohl, K. H. (1995). The composition of the continental-crust. Geochimica et Cosmochimica Acta, 59(7), 1217-1232. https://doi.org/ 10.1016/0016-7037(95)00038-2

Wells, M. L., \& Goldberg, E. D. (1991). Occurrence of small colloids in sea-water. Nature, 353(6342), 342-344. https://doi.org/10.1038/ 353342a0

Wells, M. L., Price, N. M., \& Bruland, K. W. (1995). Iron chemistry in seawater and its relationship to phytoplankton-A workshop report. Marine Chemistry, 48(2), 157-182. https://doi.org/10.1016/0304-4203(94)00055-I

Wu, J., Boyle, E., Sunda, W., \& Wen, L. S. (2001). Soluble and colloidal iron in the oligotrophic North Atlantic and North Pacific. Science, 293(5531), 847-849. https://doi.org/10.1126/science.1059251

Wu, J. F., \& Luther, G. W. (1994). Size-fractionated iron concentrations in the water column of the Western North-Atlantic Ocean. Limnology and Oceanography, 39(5), 1119-1129. https://doi.org/10.4319/lo.1994.39.5.1119

Wuttig, K., Townsend, A. T., van der Merwe, P., Gault-Ringold, M., Holmes, T., Schallenberg, C., et al. (2019). Critical evaluation of a seaFAST system for the analysis of trace metals in marine samples. Talanta, 197, 653-668. https://doi.org/10.1016/j.talanta.2019.01.047

Zhu, X. R., Prospero, J. M., \& Millero, F. J. (1997). Diel variability of soluble Fe (II) and soluble total Fe in North African dust in the trade winds at Barbados. Journal of Geophysical Research, 102(D17), 21297-21305. https://doi.org/10.1029/97jd01313 